In cooperation with the U.S. Army Corps of Engineers, Kansas City District

\title{
Two-Dimensional Direct-Current Resistivity Survey to Supplement Borehole Data in Ground-Water Models of the Former Blaine Naval Ammunition Depot, Hastings, Nebraska, September 2003
}

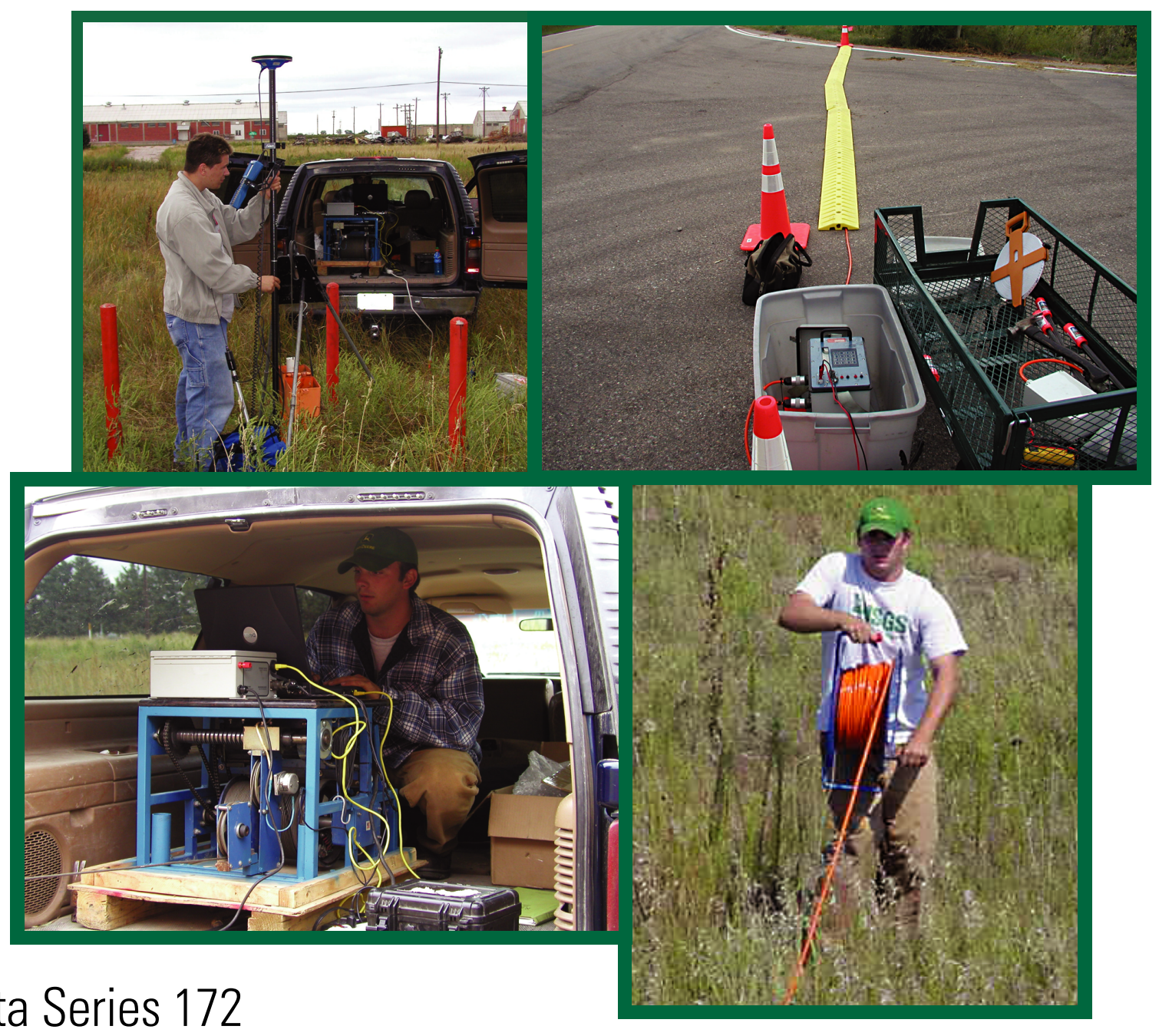


Cover. (Left top) Collection of positional data at monitoring well.

(Left bottom) Collection of borehole geophysical log.

(Right top) Speed bump used to protect cables where profile extends over roads.

(Right bottom) A set of multicore cables with 10-meter electrode spacing. 


\section{Two-Dimensional Direct-Current Resistivity Survey to Supplement Borehole Data in Ground-Water Models of the Former Blaine Naval Ammunition Depot, Hastings, Nebraska, September 2003}

By Wade H. Kress, Lyndsay B. Ball, Andrew P. Teeple, and Michael J. Turco

Data Series 172 


\section{U.S. Department of the Interior Gale A. Norton, Secretary}

\section{U.S. Geological Survey \\ P. Patrick Leahy, Acting Director}

\section{U.S. Geological Survey, Reston, Virginia: 2006}

For sale by U.S. Geological Survey, Information Services

Box 25286, Denver Federal Center

Denver, CO 80225

For more information about the USGS and its products:

Telephone: 1-888-ASK-USGS

World Wide Web: http://www.usgs.gov/

Any use of trade, product, or firm names in this publication is for descriptive purposes only and does not imply endorsement by the U.S. Government.

Although this report is in the public domain, permission must be secured from the individual copyright owners to reproduce any copyrighted materials contained within this report.

Suggested citation:

Kress, W.H., Ball, L.B., Teeple, A.P., and Turco, M.J., 2006, Two-dimensional direct-current resistivity survey to supplement borehole data in ground-water models of the former Blaine Naval Ammunition Depot, Hastings, Nebraska, September 2003: U.S. Geological Survey Data Series 172, 31 p. 


\section{Contents}

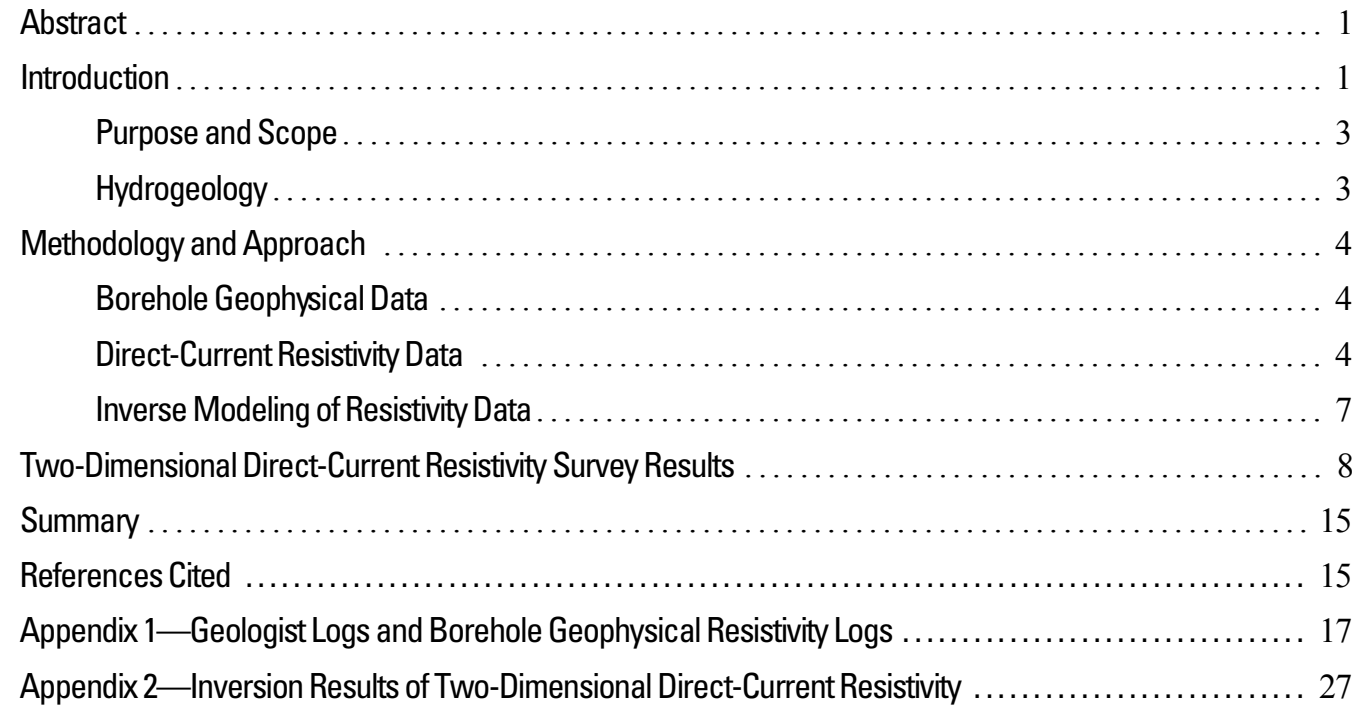

\section{Figures}

1. Map showing approximate boundary of the former Blaine Naval Ammunition Depot site ....... 2

2. Schematic diagram showing rock stratigraphy, hydrogeologic units, monitoring well

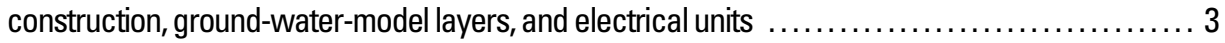

3. Maps showing two-dimensional direct-current resistivity profiles and monitoring well locations of the former NAD site at:

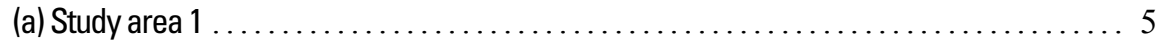

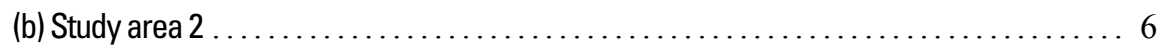

4. Photographs showing collection of (a) borehole geophysical log at monitoring well 113BB3,

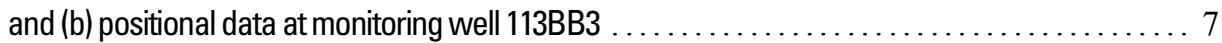

5. Photographs showing setup of two-dimensional direct-current resistivity equipment, (a) multicore cable connected to electrode, (b) resistivity meter connected to multicore cables (orange cables connected in back of unit), (c) one of 11 sets of multicore cables with 10-meter electrode spacing, and (d) speed bump used to protect cables where profile extends over roads

6. Diagrams showing geologist log superimposed on inversion results (true resistivity) of two-dimensional direct-current resistivity profile for:
(a) Section plot 1

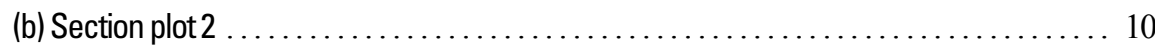

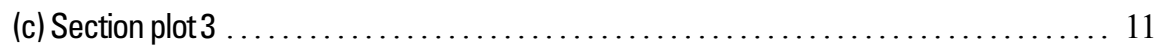

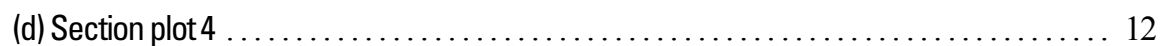

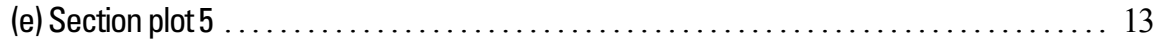

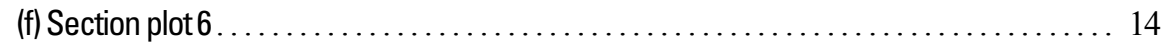


7. Diagrams showing geologist log and borehole geophysical resistivity log for monitoring well:

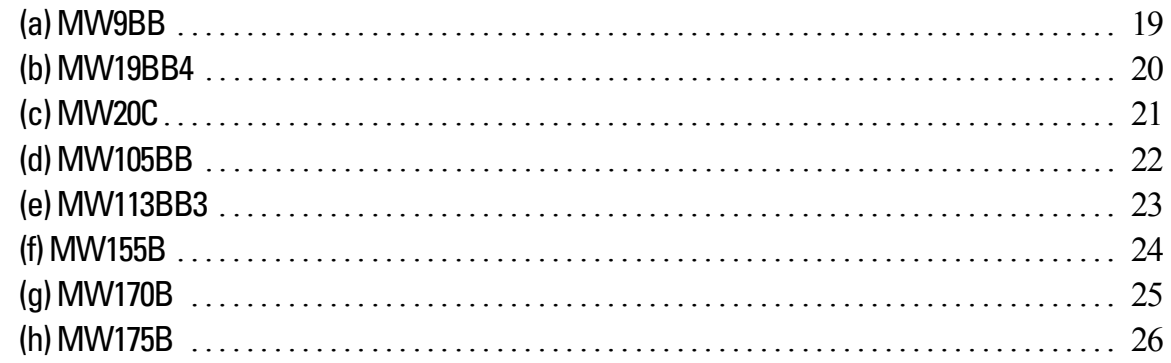

8. Diagrams showing inversion results of two-dimensional direct-current resistivity for:
(a) Profile 1
(b) Profile 2
(c) Profile 3
30

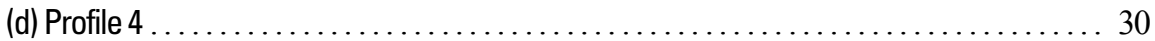

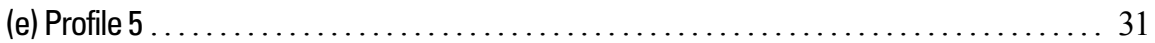

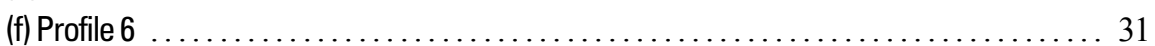

\section{Conversion Factors and Datums}

\section{Inch/Pound to SI}

\begin{tabular}{|c|c|c|}
\hline Multiply & By & To obtain \\
\hline \multicolumn{3}{|c|}{ Length } \\
\hline foot & 0.3048 & meter \\
\hline mile & 1.609 & kilometer \\
\hline
\end{tabular}

Vertical coordinate information is referenced to the North American Vertical Datum of 1988 (NAVD 88).

Horizontal coordinate information is referenced to the North American Datum of 1983 (NAD 83). Elevation, as used in this report, refers to distance above the vertical datum. 


\title{
Two-Dimensional Direct-Current Resistivity Survey to Supplement Borehole Data in Ground-Water Models of the Former Blaine Naval Ammunition Depot, Hastings, Nebraska, September 2003
}

\author{
By Wade H. Kress, Lyndsay B. Ball, Andrew P. Teeple, and Michael J. Turco
}

\begin{abstract}
The former Blaine Naval Ammunition Depot located immediately southeast of Hastings, Nebraska, was an ammunition facility during World War II and the Korean Conflict. Waste-management practices during operation and decommissioning of the former Depot resulted in soil and ground-water contamination. Ground-water models have been used by the U.S. Army Corps of Engineers to provide information on the fate and transport of contaminants on the former Depot site. During September 2003, the U.S. Geological Survey, in cooperation with the U.S. Army Corps of Engineers, Kansas City District, conducted a pilot study to collect two-dimensional direct-current resistivity data on the site along six profiles near existing monitoring wells. The inversion results of field data from five of the six two-dimensional direct-current resistivity profiles display distinct electrical stratigraphy consistent with three resistivity units (low resistivity, high resistivity, and low resistivity). These three resistivity units correlate with rockstratigraphic or hydrogeologic units described prior to this study. To interpret the resistivity profiles, additional data extending through the lower confining unit into the underlying Niobrara Formation could be used with the existing data to construct forward models for data analysis and interpretation.
\end{abstract}

\section{Introduction}

The Blaine Naval Ammunition Depot (referred to hereinafter as former NAD site) located immediately southeast of Hastings, Nebr. (fig. 1), was an active facility for loading, assembling, and packing ammunition during World War II and the Korean Conflict. Waste-management practices during the operation of the former NAD site and during the decommissioning process resulted in contamination of soil and ground water (U.S. Environmental Protection Agency, 2004). The former
NAD site later became part of the Hastings Ground Water Contamination Site, which was added to the U.S. Environmental Protection Agency's National Priorities List in 1986. In 1987, the U.S. Army Corps of Engineers (USACE) began the Remedial Investigation/Feasibility Study (RI/FS) of the former NAD site (Shaw Environmental, Inc., 2004). The RI/FS characterized the nature and extent of contamination at the former NAD site, developed and evaluated remedial action alternatives that addressed potential risk, and complied with regulatory requirements. Studies generated from the RI/FS have been used by the USACE to produce ground-water-flow models that provide information on the fate and transport of contaminants at the former NAD site (IT Corporation, 2002).

The reliability of any ground-water-flow model is dependent, in part, on the quality and quantity of data available in a study area. Borehole logs, including geologist descriptions and geophysical data, often are used in conjunction with regional bedrock topology and outcrop observation to define layers in ground-water-flow models that reflect the scale and geometry of the aquifer under study (Merry and others, 2003). In heterogeneous aquifers, lack of subsurface data is a substantial limitation to model results and one of the common sources of model error (Konikow and Bredehoeft, 1992).

Additional information on the aquifer system can be obtained by installing wells or test holes, collecting groundwater samples for chemical analysis, examining borehole logs, or conducting aquifer tests, but drilling additional wells and performing aquifer tests can be time-consuming and expensive. An alternative approach is to combine non-intrusive surface geophysical methods with a drilling and ground-water sampling program to provide additional aquifer-system information at a lower cost. Surface geophysical data can be used to interpret elevations of geologic or hydrogeologic units between wells or boreholes, vertical and horizontal distributions of hydrologic properties in the aquifer system, and vertical and horizontal locations of contaminant plumes (Stanton and others, 2003). By conducting a two-dimensional direct-current (2D-DC) 


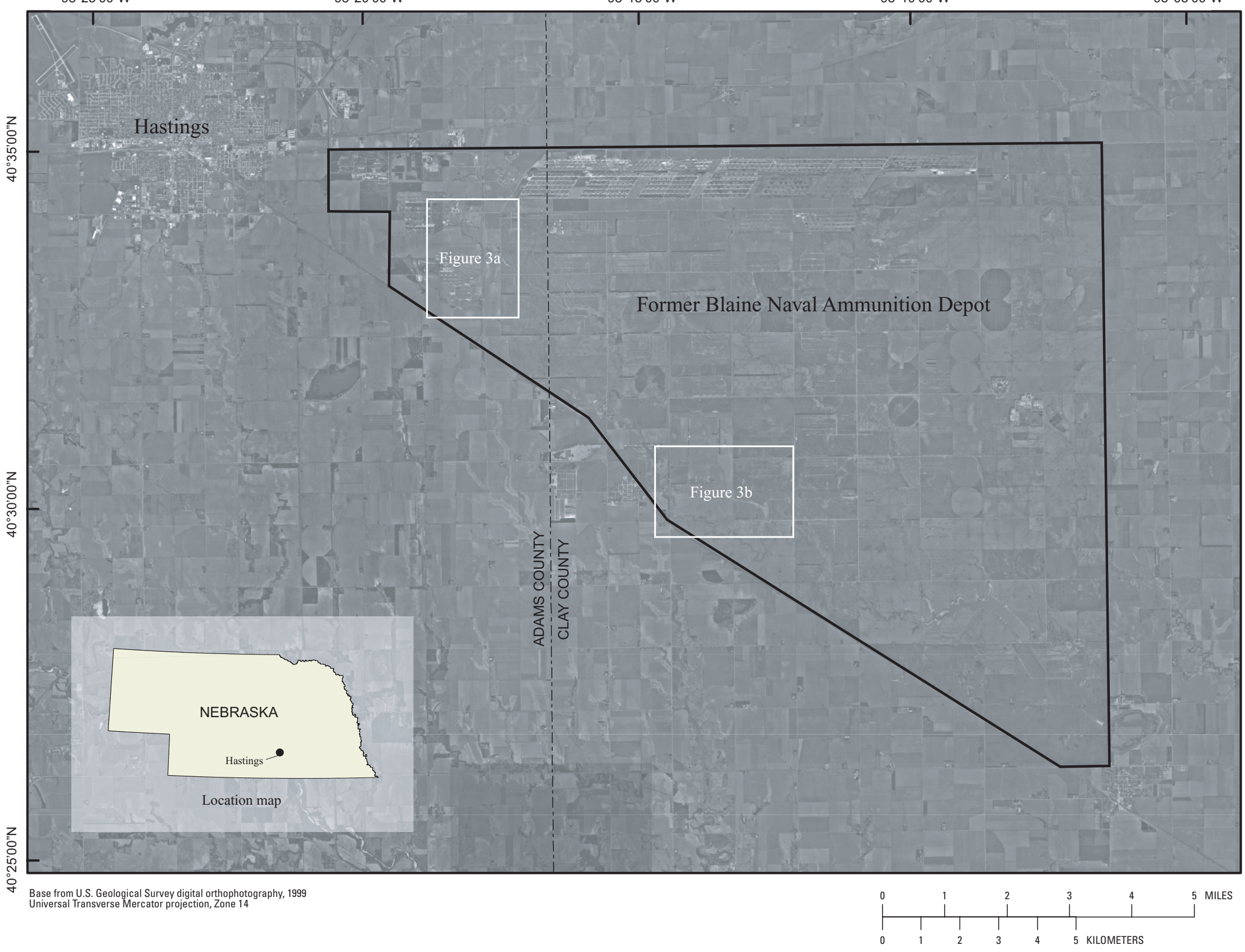

Figure 1. Approximate boundary of the former Blaine Naval Ammunition Depot site. 


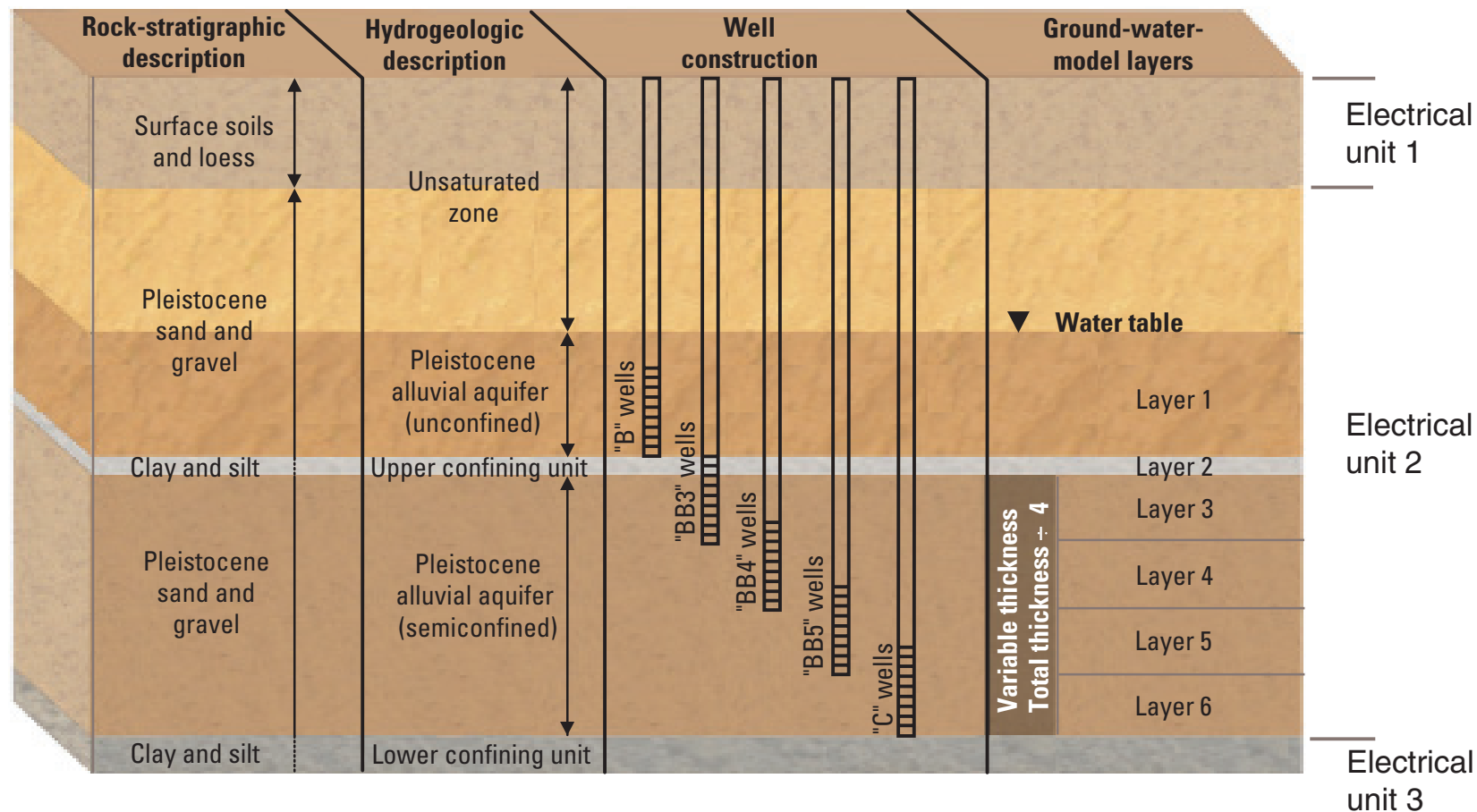

Figure 2. Schematic diagram showing rock stratigraphy, hydrogeologic units, monitoring well construction, ground-water-model layers, and electrical units (modified from IT Corporation, 2002).

resistivity surface geophysical survey in an area where boreholes are present, resistivity data can be compared to geologic, hydrogeologic, or water-quality data (from boreholes) to determine if there is a relation between these units and units of resistivity. Once a relation is established, 2D-DC resistivity surveys can be used to extend the depth, thickness, and information obtained from boreholes or can be used as an exploratory tool in areas where few or no borehole data are available. During September 2003, the U.S. Geological Survey (USGS), in cooperation with the USACE, Kansas City District, conducted a pilot study to collect 2D-DC resistivity data on the former NAD site along six profiles near existing monitoring wells.

\section{Purpose and Scope}

The purpose of this report is to describe the methods and results of a 2D-DC resistivity surface geophysical survey conducted in September 2003 on the former NAD site. Borehole resistivity data collected in selected boreholes and inversion results of six profiles of 2D-DC resistivity data are documented. The inversion results and the borehole geologic and geophysical data that were collected or used in the study were input into a three-dimensional (3D) database of the former NAD site.

\section{Hydrogeology}

The High Plains aquifer lies beneath most of the former NAD site and comprises the Pleistocene alluvial deposits and the Miocene Ogallala Formation (Keech and Dreeszen, 1968). The surface geophysical investigation of the former NAD site was conducted in two areas where the Ogallala Formation is not present.

The Niobrara Formation of Cretaceous-age limestone and chalk lies at the base of the High Plains aquifer (IT Corporation, 2002). The Niobrara Formation is overlain by unconsolidated Pleistocene deposits. The lower part of the unconsolidated Pleistocene deposits, consisting of silt and clay, is considered to be the local lower confining unit at the former NAD site. Thickness of the lower confining unit ranges from 0 to 150 feet. The upper part of the unconsolidated Pleistocene deposits is a sequence of sand and gravel that ranges from 200 to 300 feet in thickness and forms the Pleistocene alluvial aquifer, the primary source of drinking water in the Hastings area. Some areas of the Pleistocene alluvial aquifer on the former NAD site contain layers of clay and silt. In some places these clay and silt layers are as thick as 11 feet and serve as a local confining unit within the Pleistocene alluvial aquifer. About 50 feet of loess deposits overlie the Pleistocene sand and gravel (Shaw Environmental Inc., 2004).

For the purposes of the ground-water-flow model, the subsurface beneath the former NAD site in the ground-water feasibility study report (IT Corporation, 2002) is divided as follows (fig. 2): unsaturated zone, Pleistocene alluvial aquifer (unconfined part) (model layer 1), upper confining unit (model layer 2), Pleistocene alluvial aquifer (semiconfined part) (model layers 3-6), and lower confining unit. The unsaturated zone is composed of surface soils, loess, sand, and gravel. The 


\section{Two-Dimensional Direct-Current Resistivity Survey, Former Blaine Naval Ammunition Depot, September 2003}

thickness of the unsaturated zone ranges from about 95 to 115 feet. The unconfined part of the Pleistocene alluvial aquifer consists of sand, and to a lesser extent, sand and gravel and clayey or silty sand. Saturated thickness of the unconfined part of the aquifer varies but typically is about 15 feet. The (local) upper confining unit consists of silty clay, clayey silt, and clayey sand. The upper confining unit can be as thick as 11 feet; however, the thickness and extent vary throughout the former NAD site. The semiconfined part of the Pleistocene alluvial aquifer primarily consists of sand and gravel, with thin, discontinuous silty clay and clayey sand layers interbedded in the unit. The semiconfined part of the alluvial aquifer ranges from 140 to 160 feet thick. The (local) lower confining unit consists of silty clay and clayey silt overlying bedrock, but its thickness at the site is unknown.

\section{Methodology and Approach}

Using surface geophysical methods to measure the physical properties of the subsurface, such as electrical conductivity or resistivity, dielectric permittivity, magnetic permeability, density, or acoustic velocity, provides a relatively quick and inexpensive means to characterize the subsurface (Powers and others, 1999). The results (measurements) can be influenced by chemical and physical properties of soils, rocks, and pore fluids. Interpretations from these measurements can be used to image the distribution of physical properties in the subsurface (American Society for Testing and Materials, 1999).

Electrical surface geophysical methods can be used to detect changes in the electrical properties of the subsurface. The electrical properties of soils and rocks are determined by water content, mineralogical clay content, salt content, porosity, and presence of metallic minerals. However, the resistivity of the water typically has a greater effect on bulk resistivity than the soil or rock type. Variations in electrical properties of soils and rocks, either vertically or horizontally, produce variations in the electrical signature measured by surface geophysical tools. Changes in the received signal can be related to changes in the composition, extent, and physical properties of the soils and rocks within the subsurface, to the extent that differences in lithology or rock type are accompanied by differences in resistivity (U.S. Army Corps of Engineers, 1995). However, to effectively detect these differences there must be a contrast in the property measured; for example, the target to be detected or the geologic feature to be defined must have properties substantially different from background conditions (American Society for Testing and Materials, 1999). For electrical surface geophysical methods to successfully detect or define a geologic unit, the geologic unit of interest must have properties substantially different from the geologic unit immediately above or below it. Typically, clay and shale units are less resistive than sands and gravels, which in some cases can produce an electrical contrast that could be detectable with electrical surface geophysical methods (U.S. Army Corps of Engineers, 1995).
The 2D-DC resistivity method was used to collect field measurements of apparent resistivity along six profiles (fig. 3) in two study areas (fig. 1) within the former NAD site. Apparent resistivity is the resistivity of a homogeneous isotropic earth (subsurface) that will give the same resistance value for the same electrode arrangement. To estimate the distribution of resistivity for a heterogeneous anisotropic subsurface, the apparent resistivity data were processed using an inverse modeling software program (Loke, 2002). The results from this program were used to generate 2D-DC profiles of the subsurface distribution of resistivity.

Locations for six 2D-DC resistivity profiles (fig. 3) were selected by USACE, Kansas City District, to collect data in different areas throughout the former NAD site where borehole data were available. Geologist descriptions of rock units, collected by USACE during the RI/FS, were supplied for 22 monitoring wells (fig. 3) (B.J. Roberts, U.S. Army Corps of Engineers, written commun., 2003). Electromagnetic inductionresistivity borehole geophysical logs (borehole resistivity logs) were collected by the USGS during September 2003 in eight of the 22 monitoring wells. In most wells, borehole data did not extend to the lower confining unit.

\section{Borehole Geophysical Data}

Monitoring wells used in this report were named by the USACE according to the placement of the screened interval of the well within its respective aquifer. $\mathrm{BB}$ and $\mathrm{C}$ designate wells (fig. 3) screened in the upper and lower parts, respectively, of the semiconfined aquifer. B designates wells (fig. 3) screened in the unconfined aquifer (IT Corporation, 2002).

Borehole resistivity logs were collected by the USGS at eight monitoring wells with a System VI logging system (fig. 4a) using a 9512 three-coil slim-hole induction tool supplied by Century Geophysical Corporation (2004). Borehole resistivity logs were collected along profile 1 at monitoring wells MW170B and MW175B, along profile 2 at monitoring wells MW19BB4 and MW20C, along profile 3 at monitoring wells MW105BB and MW155B, and along profile 4 at monitoring wells MW9BB and MW113BB3 (fig. 3a). Positional data (horizontal and vertical) for the monitoring wells (fig. 4b) and electrodes used in the surface geophysical survey were collected using an Ashtech Z-extreme real-time kinematic global positioning system (Thales Navigation Inc., 2004). All geologist descriptions and borehole geophysical logs of the boreholes used in this report were incorporated into Oasis montaj version 6.2 (Geosoft, Inc., 2004) and are presented in appendix 1.

\section{Direct-Current Resistivity Data}

Resistivity surveys are made by transmitting current into the subsurface through two current electrodes and measuring the resulting voltage between two potential electrodes. The 


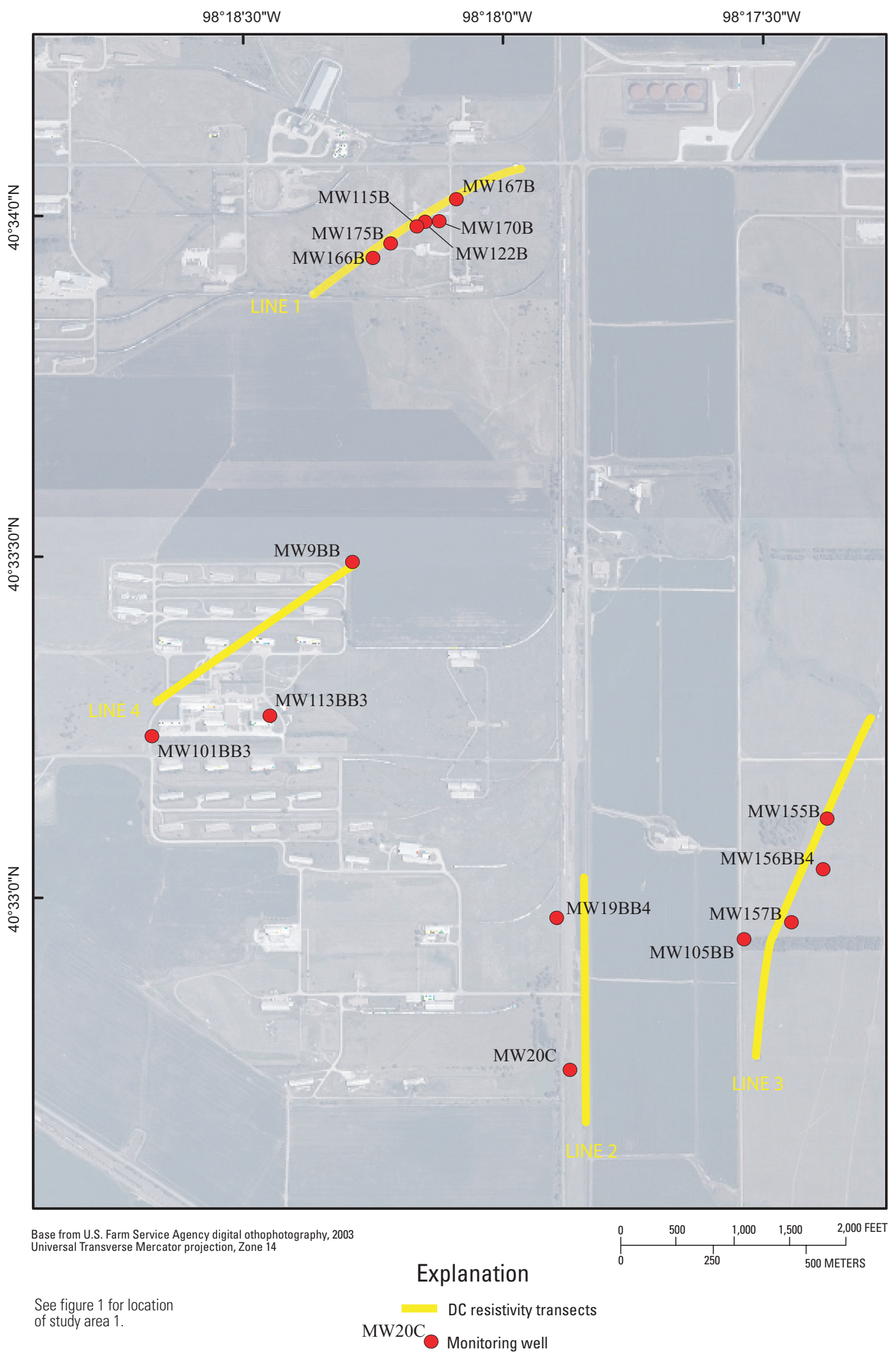

Figure 3a. Two-dimensional direct-current resistivity profiles and monitoring well locations of the former NAD site at study area 1. 


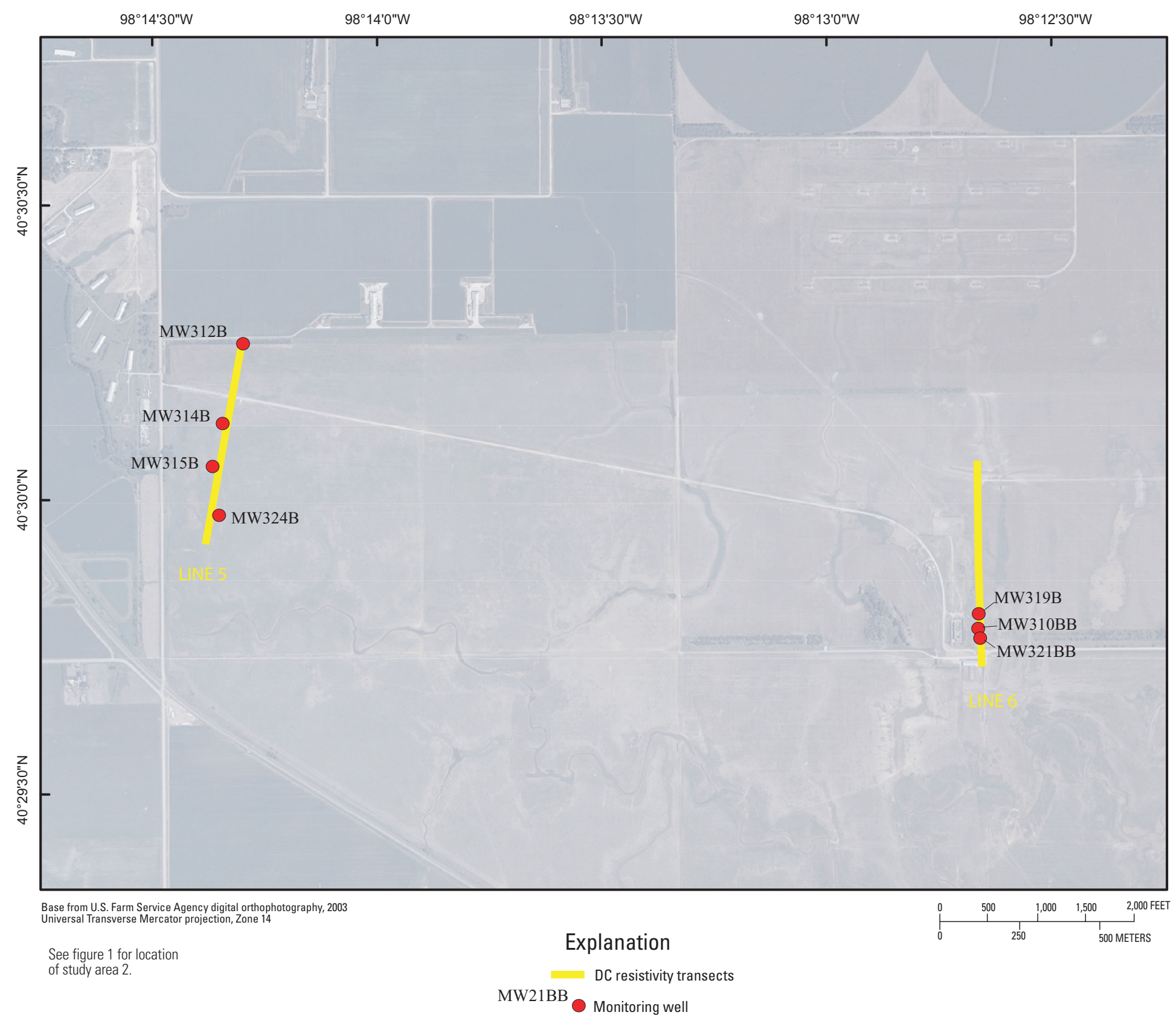

Figure 3b. Two-dimensional direct-current resistivity profiles and monitoring well locations of the former NAD site at study area 2. 
(a)

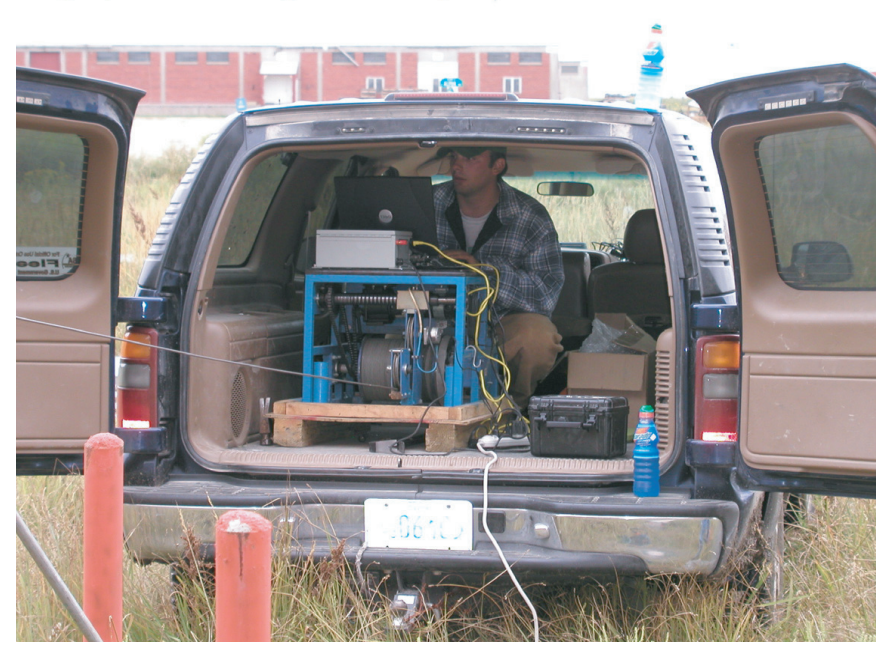

(b)

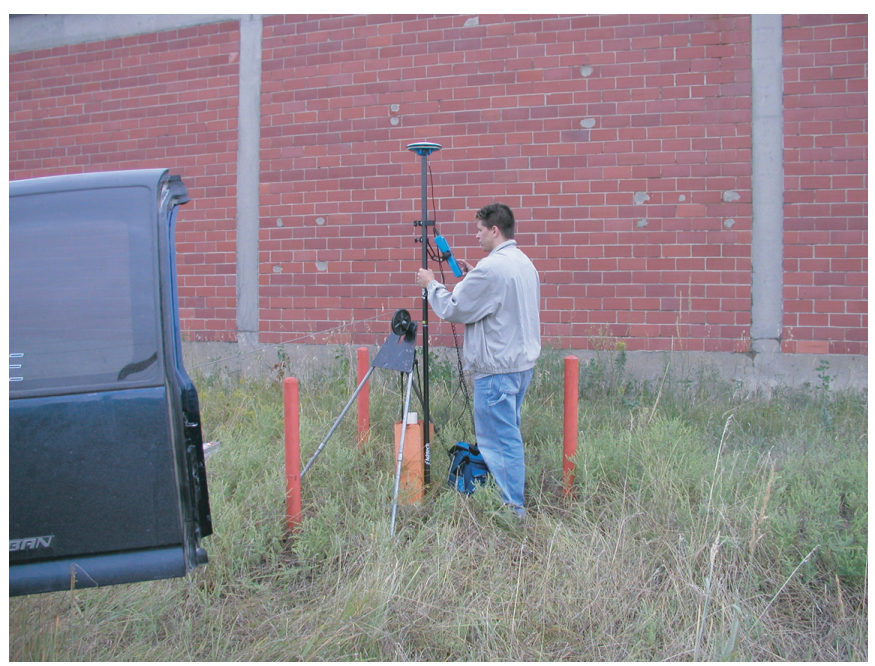

Figure 4. Collection of (a) borehole geophysical log at monitoring well 113BB3 and (b) positional data at monitoring well $113 \mathrm{BB} 3$.

resistance, $R$, then is computed by dividing the measured voltage by the transmitted current, as described by Ohm's law:

$$
R=V / I,
$$

where $I$ is the current applied through the current electrodes, and $V$ is the potential difference or voltage measured by the potential electrodes. The apparent resistivity of the subsurface is calculated by multiplying each resistance by a geometric factor determined by the geometry and the spacing of the electrode array (Zohdy, 1974). Deeper apparent resistivity measurements can be obtained by increasing the electrode spacing. The DC resistivity method is described in detail by Grant and West (1965) and Zohdy (1974).

Resistivity data can be collected using different techniques. Traditionally, individual resistivity measurements are made by keeping the central point of the array at the same location and increasing the electrode spacing to obtain measurements at increasing depths, a technique known as resistivity sounding. The central point of the array then is moved and the process repeated until the desired area is covered. An alternative to resistivity sounding is resistivity profiling, in which a large number of electrodes are connected to a multiconductor cable and controlled by an automatically switching resistivity meter. The resistivity meter uses an initial set of four electrodes (two current electrodes and two potential electrodes) to make a measurement, switches to another four electrodes, and then continues until all electrodes have been used in a sequence of different spacings to create a 2D section of apparent resistivity.

Using the Wenner-Schlumberger array (Zohdy, 1974), 2D-DC resistivity data at the former NAD site were collected using an IRIS Syscal R1 Plus switching unit (IRIS Instruments, 2004). Using four electrodes at a time, the unit switches among a combination of 11 sets of multicore cables (fig. 5c) with six electrodes each at 10-meter spacing to collect multiple points from a single layout. After the initial section of data was collected, the first two cables of 12 electrodes were moved ahead of the survey profile. A partial section of data then was collected using the previous 54 electrodes (electrodes 13-66) and the 12 electrodes (electrodes 67-78) that were just moved. This process, known as the roll-along technique, was continued until all data along the desired profile length were collected. Plastic speed bumps were used to protect the cables when profiles extended over roads (fig. 5d). The data from the roll-alongs were combined into a single apparent resistivity dataset during processing.

\section{Inverse Modeling of Resistivity Data}

Apparent resistivity, as calculated from the field measurements, is the electrical resistivity of an equivalent electrically homogeneous isotropic subsurface and is used to represent the average resistivity of the heterogeneous subsurface (Loke, 2000). To estimate the "true" subsurface resistivity, an inversion program develops a 2D model consisting of rectangular blocks of individual resistivities. The inversion program then determines the calculated system response of that model, the calculated apparent resistivity, on the basis of the collected field data properties. The root mean square (RMS) difference between the measured and calculated apparent resistivities is used to determine the accuracy of the model. The inversion program then attempts to reduce the RMS difference by altering the model resistivity values, and the apparent resistivity is recalculated; this alteration is known as an iteration. When the RMS difference between the calculated and measured apparent resistivity no longer improves substantially between iterations (more than 1 percent between iterations), a solution is reached. This final model represents a non-unique estimate of the true $2 \mathrm{D}$ 


\section{Two-Dimensional Direct-Current Resistivity Survey, Former Blaine Naval Ammunition Depot, September 2003}

(a)

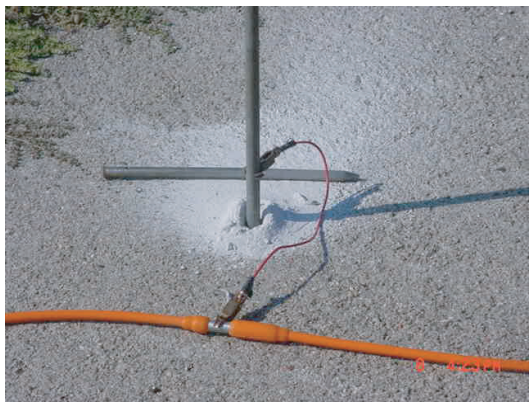

(b)

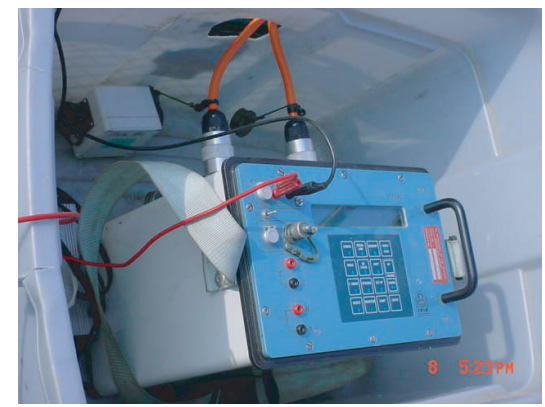

(c)

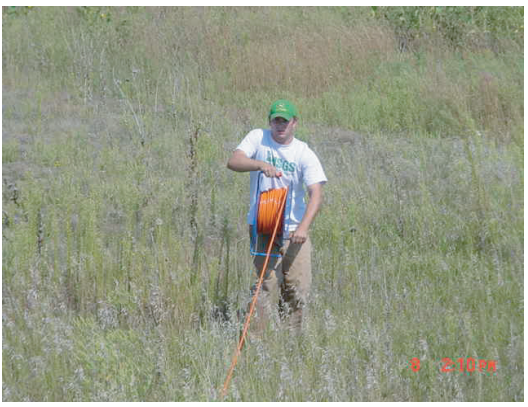

(d)

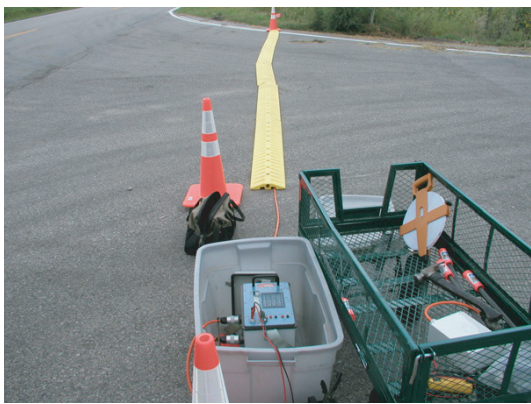

Figure 5. Setup of two-dimensional direct-current resistivity equipment, (a) multic ore cable connected to electrode, (b) resistivity meter connected to multicore cables (orange cables connected in back of unit), (c) one of 11 sets of multicore cables with 10-meter electrode spacing, and (d) speed bump used to protect cables where profile extends over roads.

distribution of subsurface resistivity. This inversion process is described in detail by Loke (2003). DC resistivity data were inverted using the finite-element method with the least-squares approximation using RES2DINV version 3.54w (Geotomo Software, 2005)

\section{Two-Dimensional Direct-Current Resistivity Survey Results}

Resistivity data were processed and inverted, then input into Oasis montaj version 6.2 (Geosoft, Inc., 2004). The inversion results of the resistivity data are displayed as gridded, 2D profiles. The same vertical and horizontal scales were used between all profiles, with distance from the origin of the profile on the $\mathrm{x}$-axis and elevation above NAVD 88 on the y-axis.

Resistivity data were gridded using the bi-directional line gridding method with a 0.25 -foot cell size in Oasis montaj version 6.2 (Geosoft, Inc., 2004) and plotted as image maps ranging from 0 to $648 \mathrm{ohm}$-meters (appendix 2). To provide an alternative and complimentary presentation of the profiles, available geologist logs from monitoring wells were plotted against the inversion results of the 2D-DC resistivity data and referred to as section plots (fig. 6).

The electrical stratigraphy in five of the six section plots (fig. 6b-f) displays three distinct electrical units-(from land surface downward) unit 1, a low-resistivity zone (less than 216 ohm-meters); unit 2, a high-resistivity unit (greater than 216 ohm-meters); and unit 3, a low-resistivity unit (less than 216 ohm-meters). The inversion results of the 2D-DC resistivity data in section plot 1 show discontinuity in unit 2 , which is separated by two vertical low-resistivity (less than $216 \mathrm{ohm}$ meters) features along the profile. Section plots 2-6 all show a continuous unit 2. To illustrate the three-unit electrical stratigraphy, the $216 \mathrm{ohm}$-meter line has been displayed in the inversion results for section plots 1-6.

Electrical unit 1 correlates with the surface soils and loess deposits of the upper part of the unsaturated zone (fig. 2). Electrical unit 2 , which is more resistive than unit 1 , correlates with the unconsolidated sand and gravel deposits that compose the lower part of the unsaturated zone and the Pleistocene alluvial aquifer. Unit 3, which is less resistive, correlates with the clay and silt of the lower part of the unconsolidated Pleistocene deposits that compose the upper part of the lower confining unit.

Geologist logs from MW20C located on profile 2 (fig. 6b) extend to the lower confining unit. Although the full range of depth of the profile does not extend to the top of the lower confining unit identified in the geologist logs, the southernmost elevation of electrical unit 2 in profile 2 and the elevation of the top of the lower confining unit identified in MW20C are very similar. Because, in many cases, geologist logs from the existing monitoring wells did not extend to the total depth of the 2D-DC resistivity profiles, it would be difficult to develop interpretations identifying the top of the lower confining unit along each profile with the existing data. To interpret the 2D-DC resistivity profiles, additional data such as geologist 

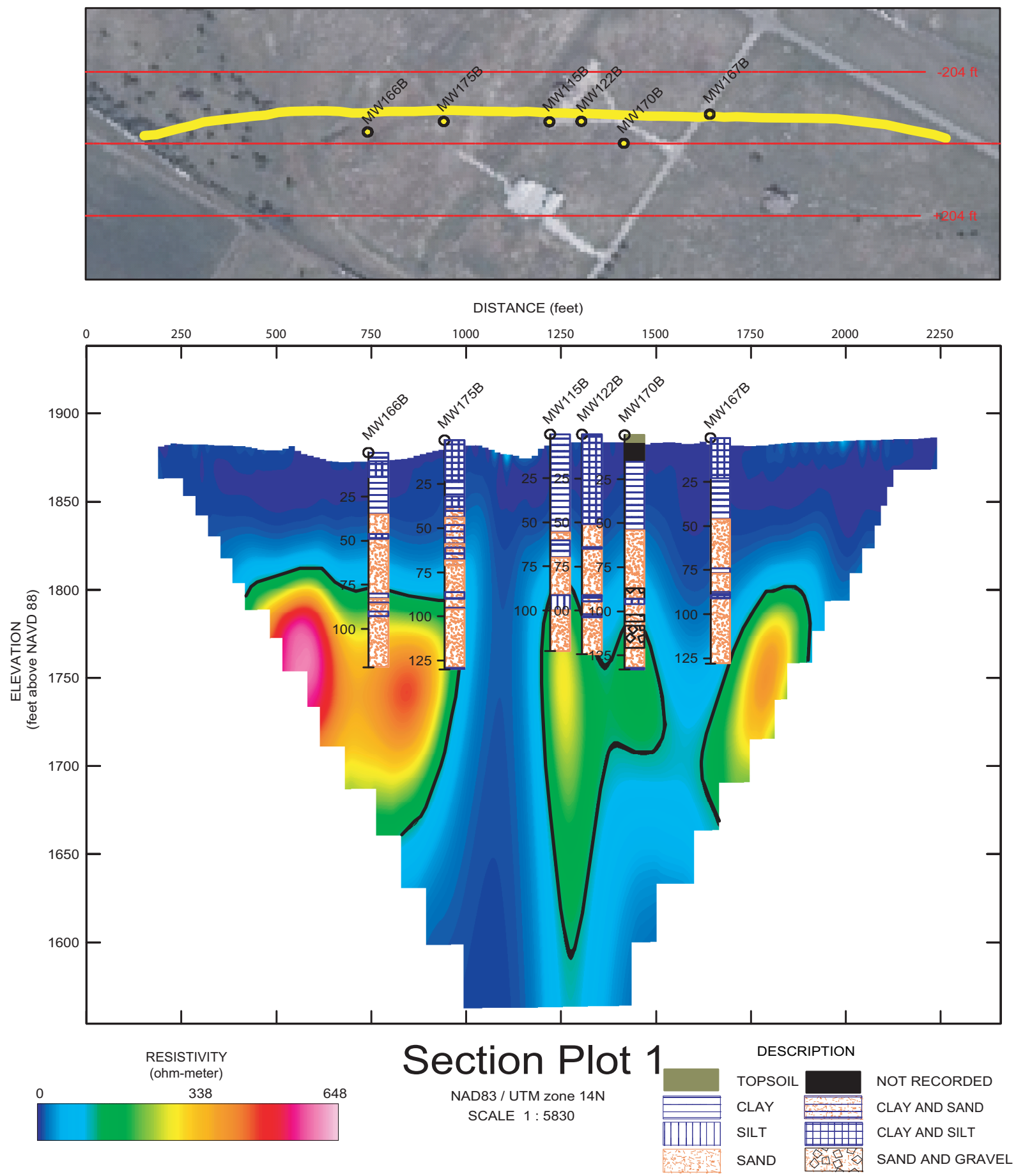

Figure 6a. Geologist log (B.J. Roberts, U.S. Army Corps of Engineers, written commun., 2003) superimposed on inversion results (true resistivity) of two-dimensional direct-current resistivity profile for section plot 1. 

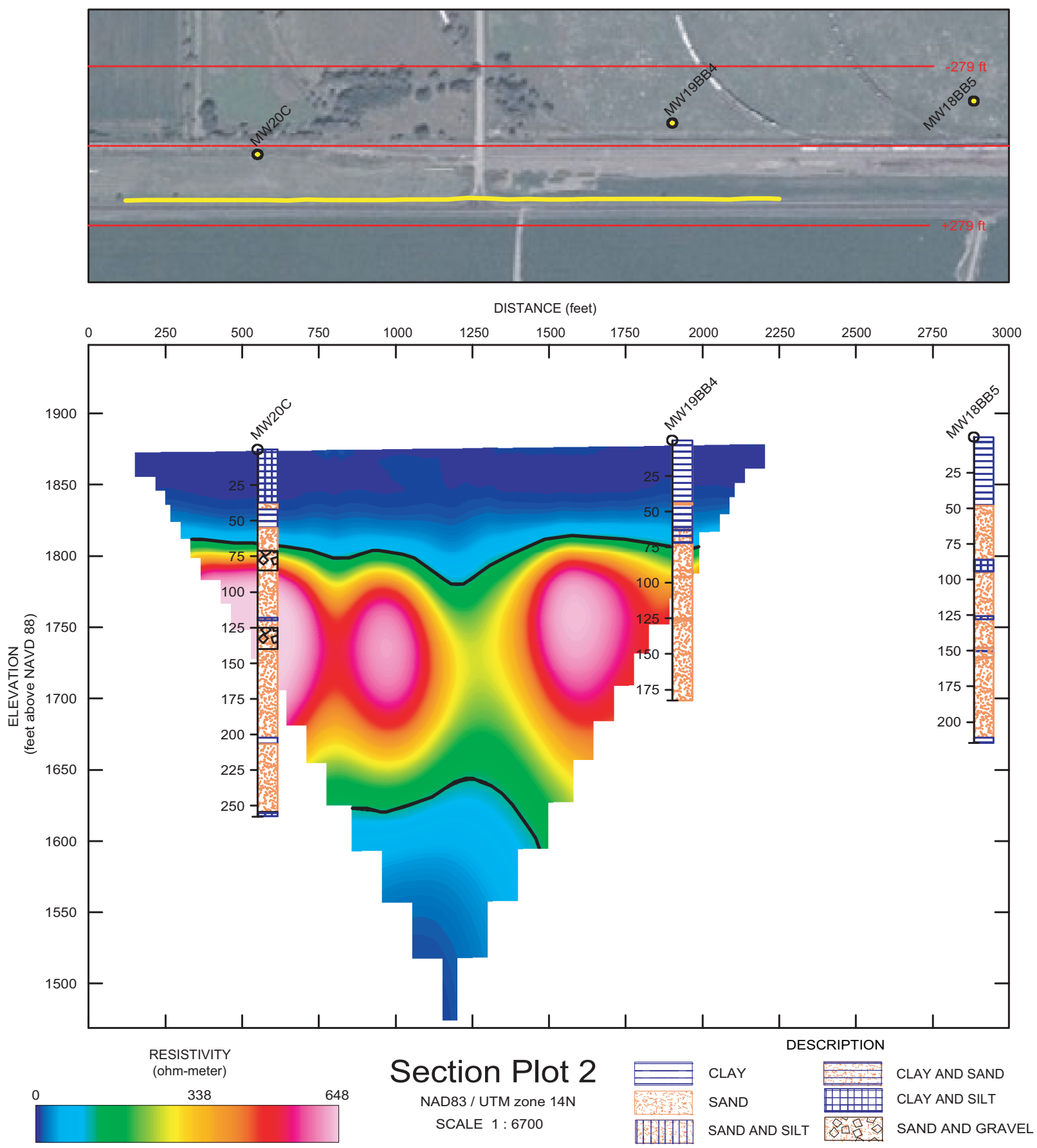

Figure 6b. Geologist log (B.J. Roberts, U.S. Army Corps of Engineers, written commun., 2003) superimposed on inversion results (true resistivity) of two-dimensional direct-current resistivity profile for section plot 2. 

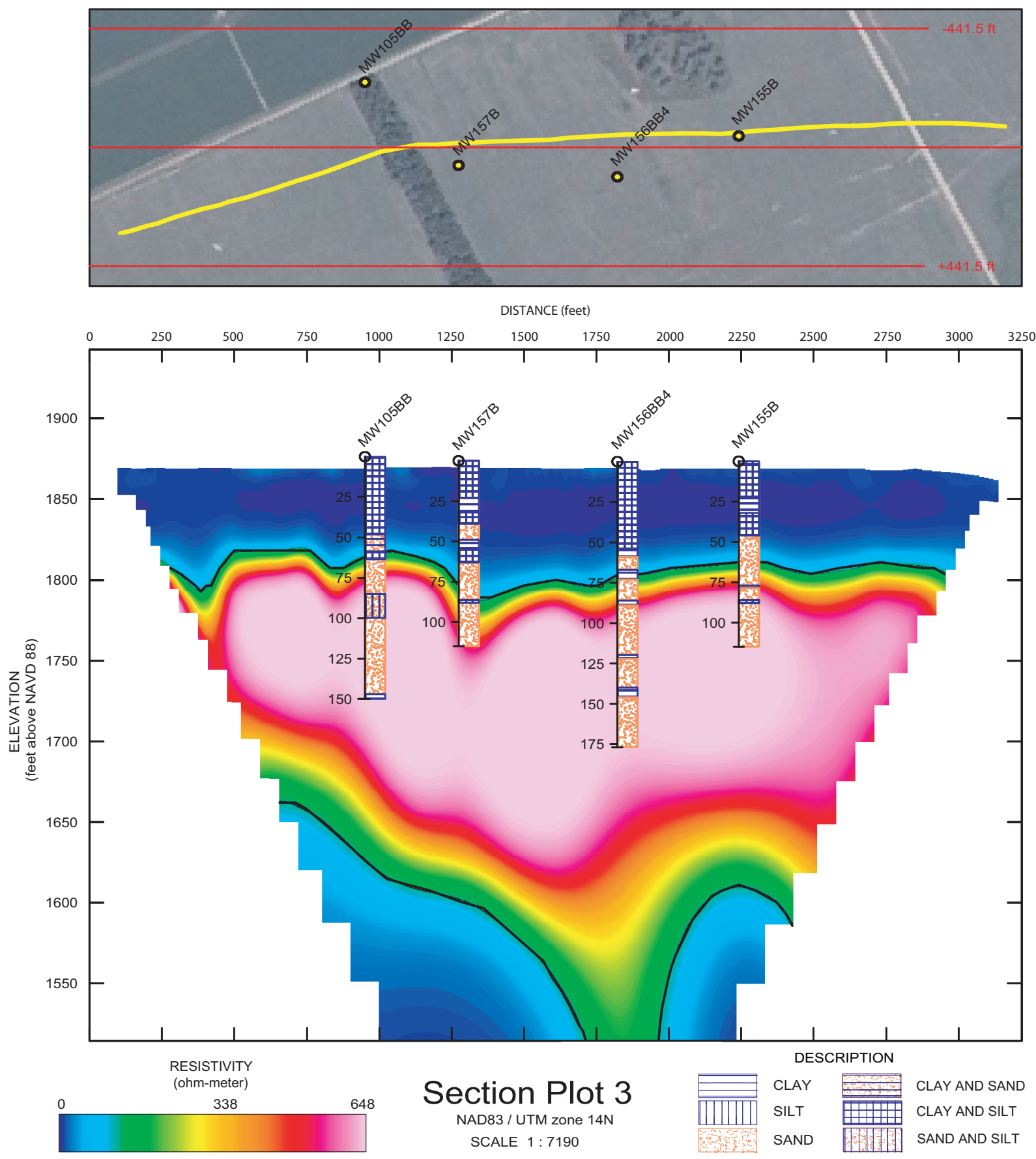

Figure 6c. Geologist log (B.J. Roberts, U.S. Army Corps of Engineers, written commun., 2003) superimposed on inversion results (true resistivity) of two-dimensional direct-current resistivity profile for section plot 3. 

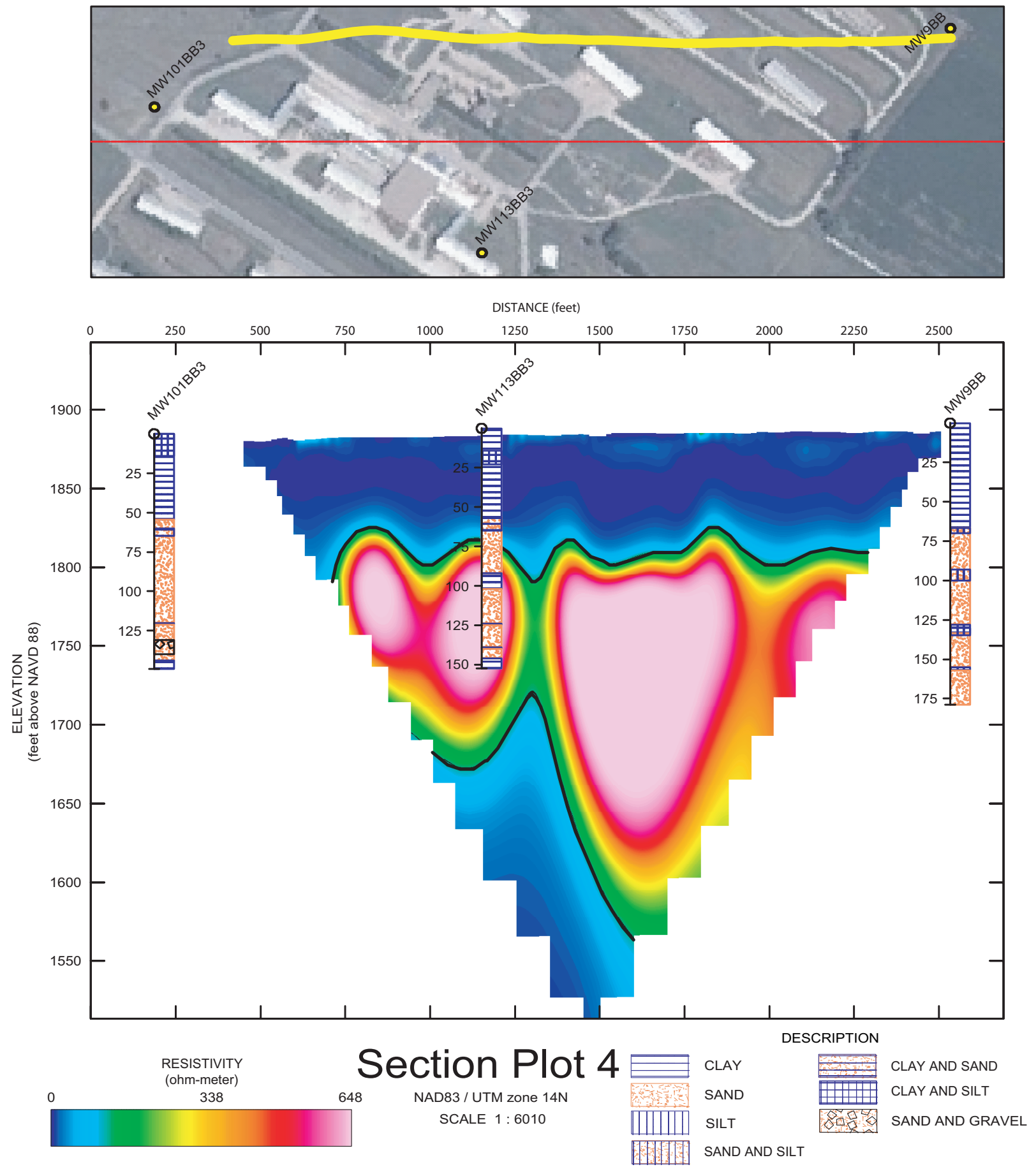

Figure 6d. Geologist log (B.J. Roberts, U.S. Army Corps of Engineers, written commun., 2003) superimposed on inversion results (true resistivity) of two-dimensional direct-current resistivity profile for section plot 4. 

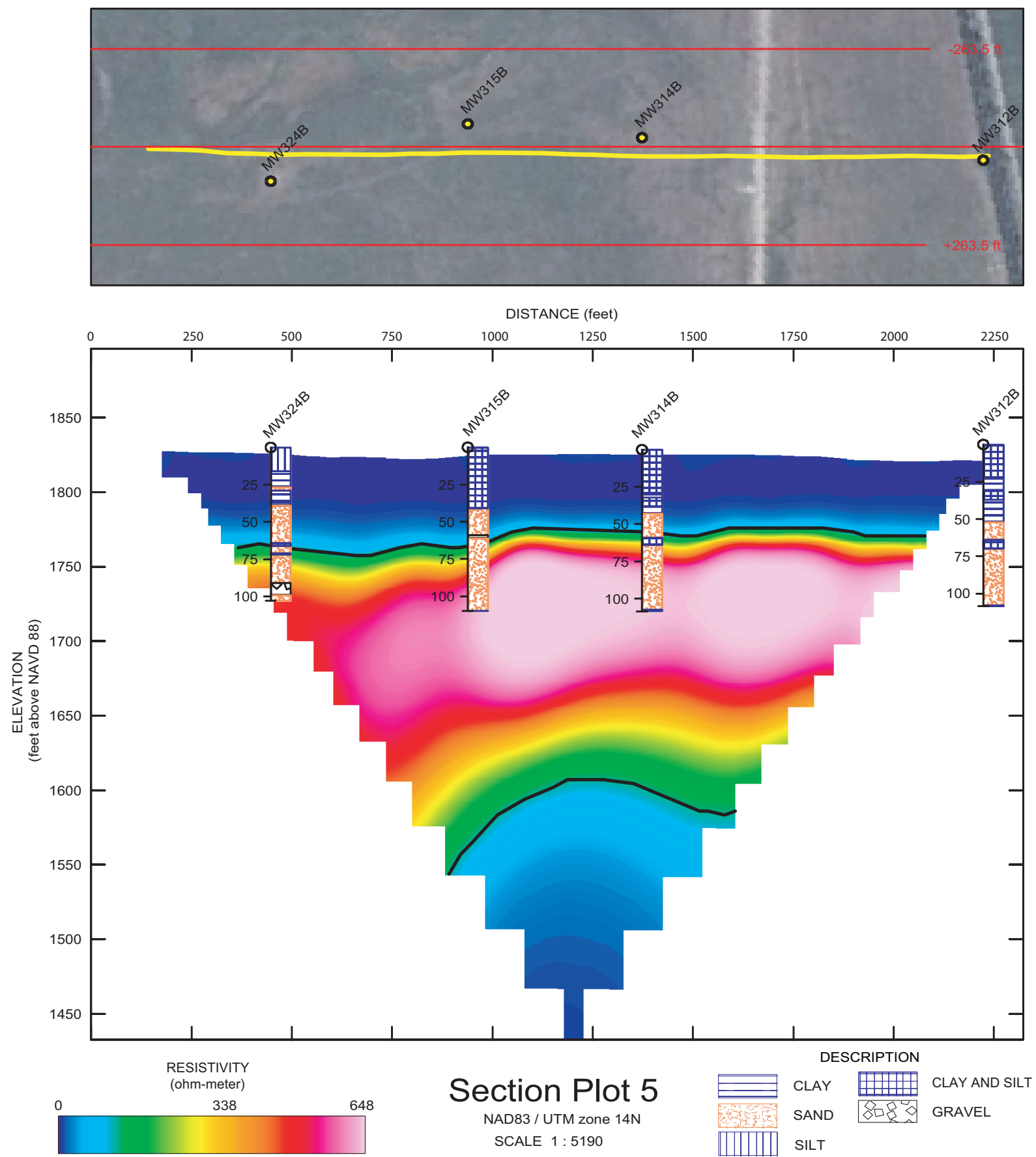

Figure 6e. Geologist log (B.J. Roberts, U.S. Army Corps of Engineers, written commun., 2003) superimposed on inversion results (true resistivity) of two-dimensional direct-current resistivity profile for section plot 5 . 

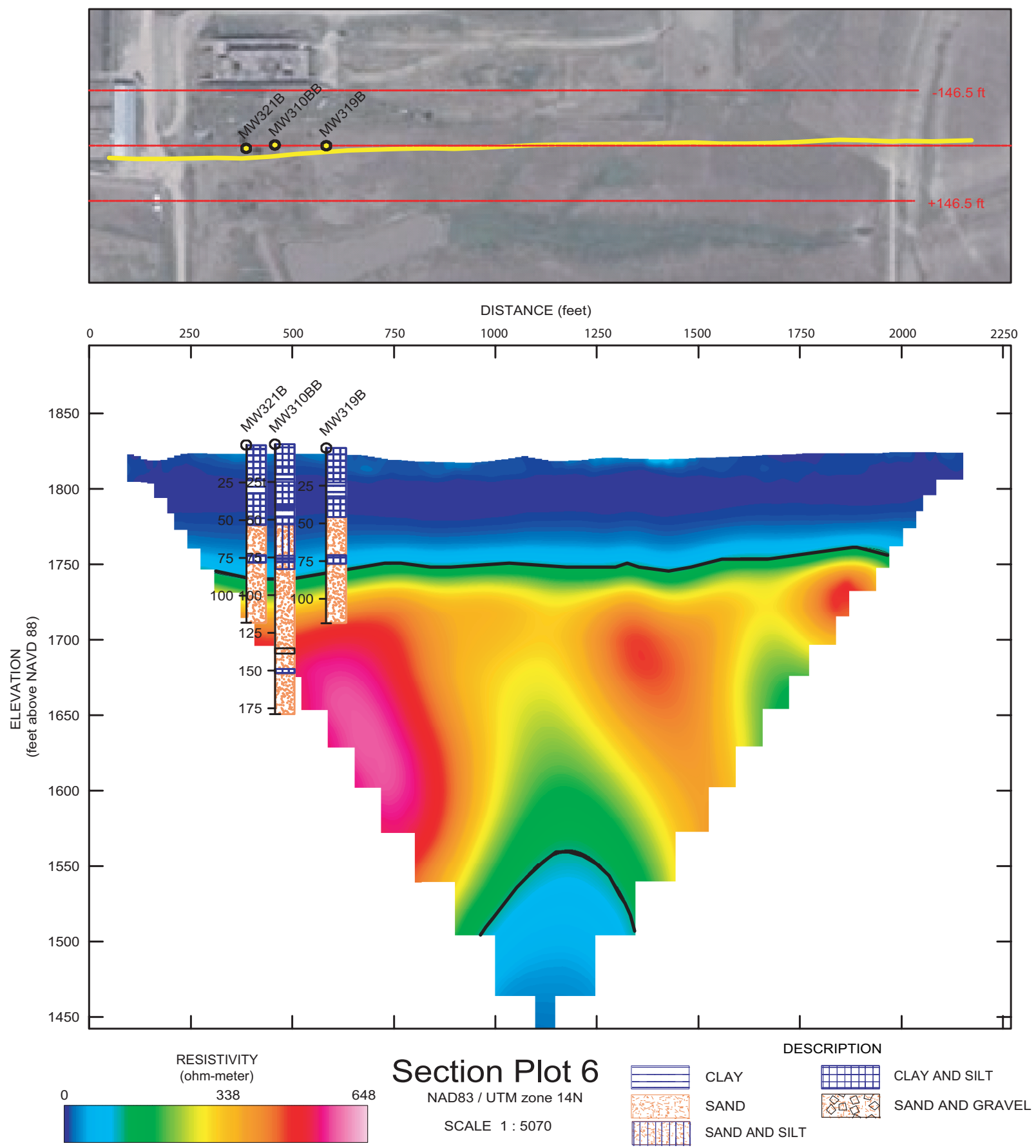

Figure 6f. Geologist log (B.J. Roberts, U.S. Army Corps of Engineers, written commun., 2003) superimposed on inversion results (true resistivity) of two-dimensional direct-current resistivity profile for section plot 6 . 
and borehole resistivity logs or other surface geophysical data extending beyond the lower confining unit into the Niobrara Formation could be used with the existing data to construct forward models for data analysis and interpretation similar to the method identified in Kress and Teeple (2005).

The results of this pilot study have been compiled into Oasis montaj, which serves as a 3D database that allows the user to graphically display and compare the results of geologic and geophysical data collected at the former NAD site. The database for this pilot study was designed to allow input of additional geologic or geophysical data that could be used to determine the effectiveness of using 2D-DC resistivity data to extend hydrogeologic contacts between existing or new monitoring wells.

\section{Summary}

The former Blaine Naval Ammunition Depot (former NAD site) located immediately southeast of Hastings, Nebr., was an ammunition facility during World War II and the Korean Conflict. Waste-management practices during the operation and decommissioning process of the former NAD site resulted in soil and ground-water contamination. Ground-water models have been used by the U.S. Army Corps of Engineers (USACE) to provide information on the fate and transport of contaminants on the former NAD site.

The reliability of any ground-water-flow model depends, in part, on the quality and quantity of data available. In heterogeneous aquifers, lack of subsurface data substantially limits model results and is one of the common sources of model error. Additional information on the aquifer system can be obtained by installing wells or test holes, collecting ground-water samples for chemical analysis, examining borehole logs, or conducting aquifer tests, but drilling additional wells and performing aquifer tests can be time-consuming and expensive. An alternative approach is to combine non-intrusive surface geophysical methods with a drilling and ground-water sampling program to provide additional aquifer-system information at a lower cost.

During September 2003, the U.S. Geological Survey, in cooperation with USACE, Kansas City District, conducted a pilot study to collect two-dimensional direct-current (2D-DC) resistivity data on the former NAD site along six profiles near existing monitoring wells. The inversion results of field data from five of the six 2D-DC resistivity profiles display distinct electrical stratigraphy consistent with three resistivity units (low resistivity, high resistivity, and low resistivity). These three resistivity units correlate with surface soils and loess deposits of the upper part of the unsaturated zone (unit 1), the unconsolidated sand and gravel deposits that compose the lower part of the unsaturated zone and the Pleistocene alluvial aquifer (unit 2), and the clay and silt of the lower part of the unconsolidated Pleistocene deposits that compose the upper part of the lower confining unit.
To interpret the 2D-DC resistivity profiles, additional data such as geologist and borehole resistivity logs or other surface geophysical data extending through the lower confining unit into the underlying Niobrara Formation could be used with the existing data to construct forward models for data analysis and interpretation.

\section{References Cited}

American Society for Testing and Materials, 1999, Standard guide for selecting surface geophysical methods, in 1999 Annual book of ASTM standards: West Conshohocked, Pa., v. 04.08, p. 6,429-6,499.

Century Geophysical Corporation, 2004, 9512 logging tool: accessed April 23, 2004, at http://www.century-geo.com/ 9512-index.html

Geosoft, Inc., 2004, Oasis montaj version 6.2: Toronto, Ontario, Canada, accessed October 2005 at http://www.geosoft.com/

Geotomo Software, 2005, RES2DINV version 3.54w: accessed October 2005 at http://www.geoelectrical.com

Grant, F.S., and West, G.F., 1965, Interpretation theory in applied geophysics, part 3-Electrical conduction and electromagnetic induction methods: New York, McGraw-Hill, p. 384-572.

IT Corporation, 2002, Ground water feasibility study report, operable unit no. 14, former Blaine Naval Ammunition Depot, Hastings, Nebraska: IT Corporation, chap. 1, p. 2-27, fig. 1-2.

IRIS Instruments, 2004, Syscal R1 Switch Plus: accessed September 21, 2004, at http://www.iris-instruments.com/ Pdf\%20file/R1Plus_72_Gb.pdf

Keech, C.H., and Dreeszen, V.H., 1968, Availability of ground water in Adams County, Nebraska: U.S. Geological Survey Hydrologic Investigations Atlas HA-287, 7 maps.

Konikow, L F. and Bredehoeft, J.D., 1992, Ground water models cannot be validated: Advances in Water Resources, v. 15 , no. 1 , p. $75-83$.

Kress, W. H., and Teeple, A.P., 2005, Two-dimensional resistivity investigation of the North Cavalcade Street site, Houston, Texas, August 2003: U.S. Geological Survey Scientific Investigations Report 2005-5205, 27 p.

Loke, M.H., 2000, Electrical imaging surveys for environmental and engineering studies-A practical guide to 2-D and 3-D surveys: $62 \mathrm{p}$.

Loke, M.H., 2002, Tutorial-2-D and 3-D electrical imaging surveys: 28 p., accessed December 1, 2003, at http://www.geoelectrical.com

Loke, M.H., 2003, RES2DINV version 3.52w-Rapid 2D resistivity and IP inversion using the least-squares method: Geoelectrical Imaging 2-D and 3-D, Geotomo Software, 125 p., accessed August 10, 2003, at http://www.geoelectrical.com

Merry, A.G., Martin, P.J., and Sussman, J., 2003, Importance of local geologic structure in a regional groundwater flow and 
contaminant transport model for Lansing, Michigan, in MODFLOW and more 2003-Understanding through Modeling, Golden, Colorado, September 17-19, 2003, Proceedings: International Ground Water Modeling Center, v. II, p. 655-660.

Powers, C.J., Wilson, Joanna, Haeni, F.P., and Johnson, C.D., 1999, Surface-geophysical investigation of the University of Connecticut landfill, Storrs, Connecticut: U.S. Geological Survey Water-Resources Investigations Report 99-4211, 34 p.

Shaw Environmental, Inc., 2004, Kansas City Total Environment Restoration Contract-Task Order-TO 001 Former Blaine NAD, Hastings NE: accessed September 21, 2004, at http://www.terc-itcorp.com/kcterc/task.html

Stanton, G.P., Kress, Wade, Hobza, C.M., and Czarneci, J.B., 2003, Possible extent and depth of salt contamination in ground water using geophysical techniques, Red River Aluminum site, Stamps, Arkansas, April 2003: U.S. Geolog- ical Survey Water-Resources Investigations Report 03-4292, $28 \mathrm{p}$.

Thales Navigation Inc., 2004, Land surveying solutionsZ-Extreme: accessed September 21, 2004, at http://products.thalesnavigation.com/en/products/ product.asp?PRODID=38

U.S. Army Corps of Engineers, 1995, Geophysical exploration for engineering and environmental investigations: Engineering Manual 1110-1-1802, chap. 4, 57 p.

U.S. Environmental Protection Agency, 2004, National Priority List sites in the Midwest, Nebraska-Hastings Ground Water Contamination: accessed September 21, 2004, at http://www.epa.gov/region7/cleanup/npl_files/index.htm

Zohdy, A.A.R, Eaton, G.P., and Mabey, D.R., 1974, Application of surface geophysics to ground-water investigations: U.S. Geological Survey Techniques of Water-Resources Investigations book 2, chap. D1, $116 \mathrm{p}$. 


\section{Appendix 1-Geologist Logs ${ }^{1}$ and Borehole Geophysical Resistivity Logs}


Blank Page 


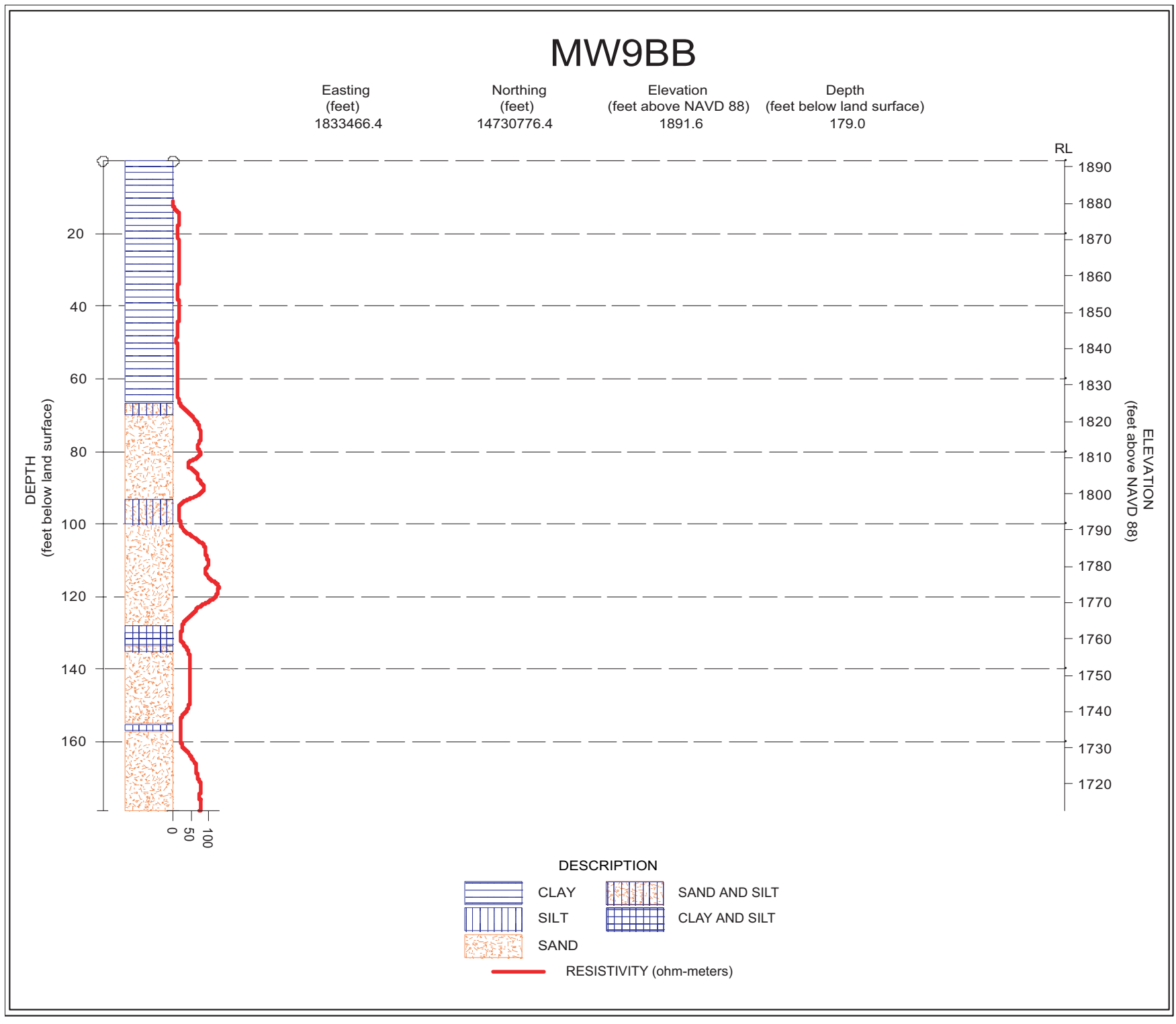

Figure 7a. Geologist log and borehole geophysical resistivity log for monitoring well MW9BB. 


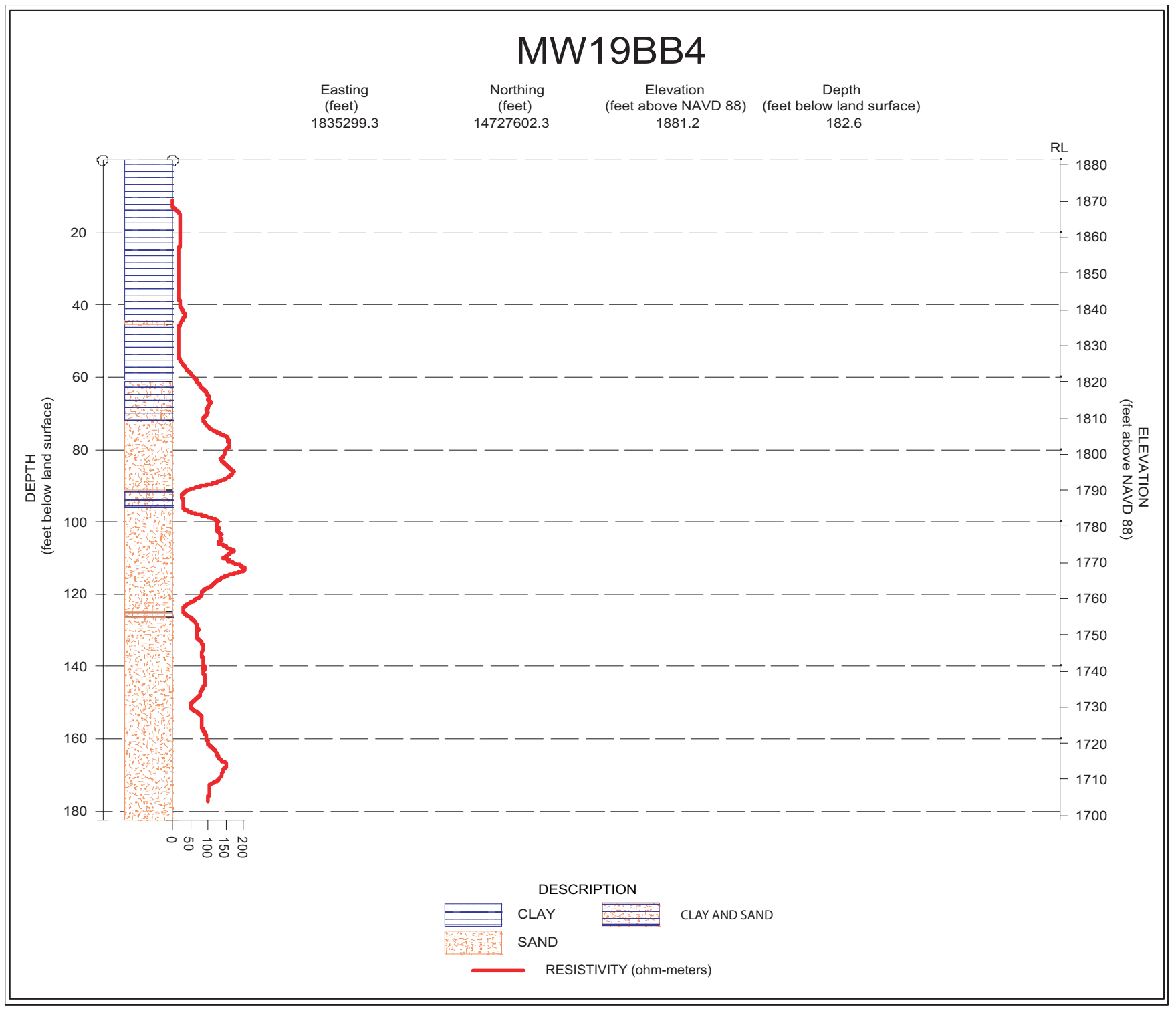

Figure 7b. Geologist log and borehole geophysical resistivity log for monitoring well MW19BB4. 


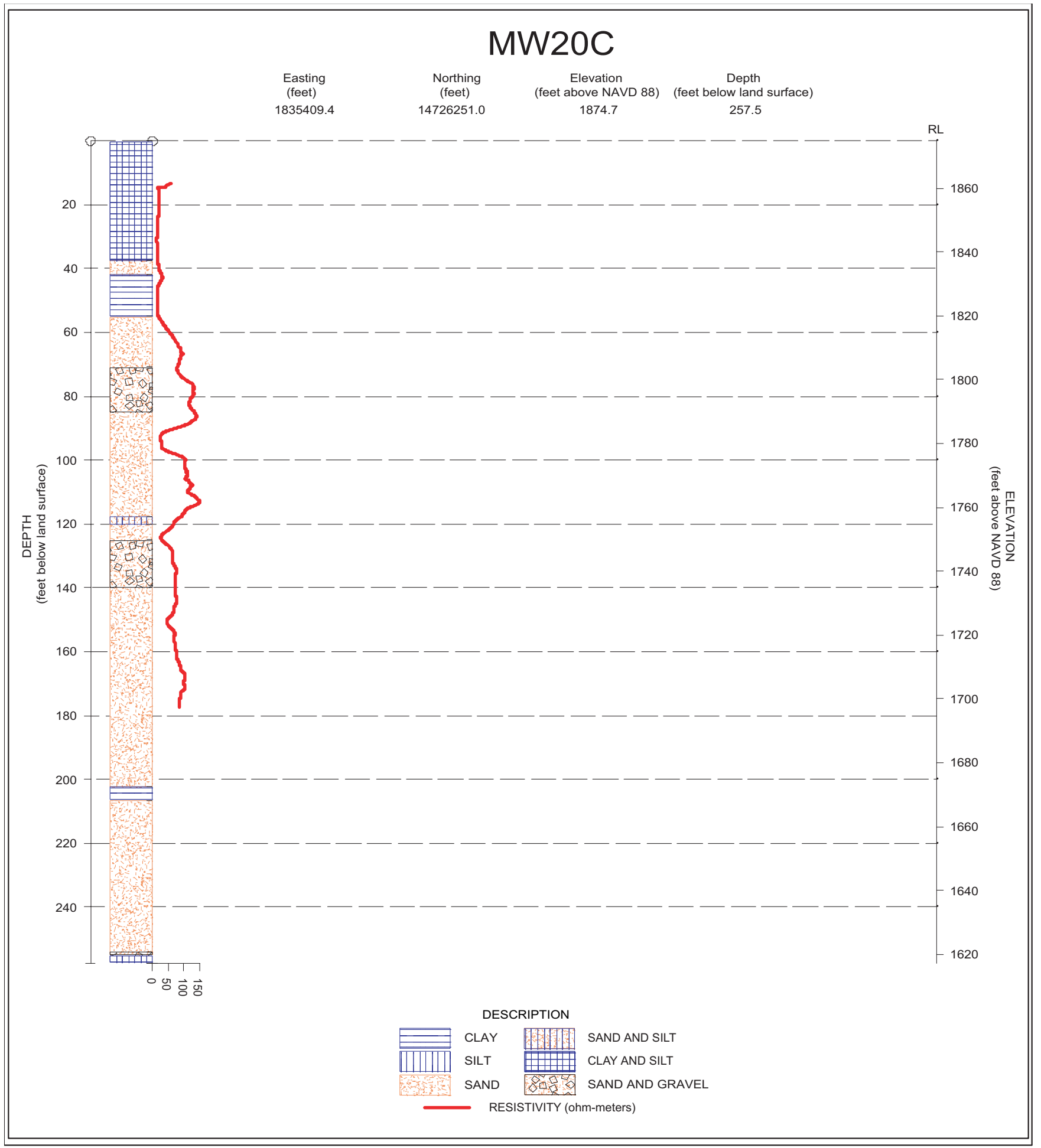

Figure 7c. Geologist log and borehole geophysical resistivity log for monitoring well MW20C. 


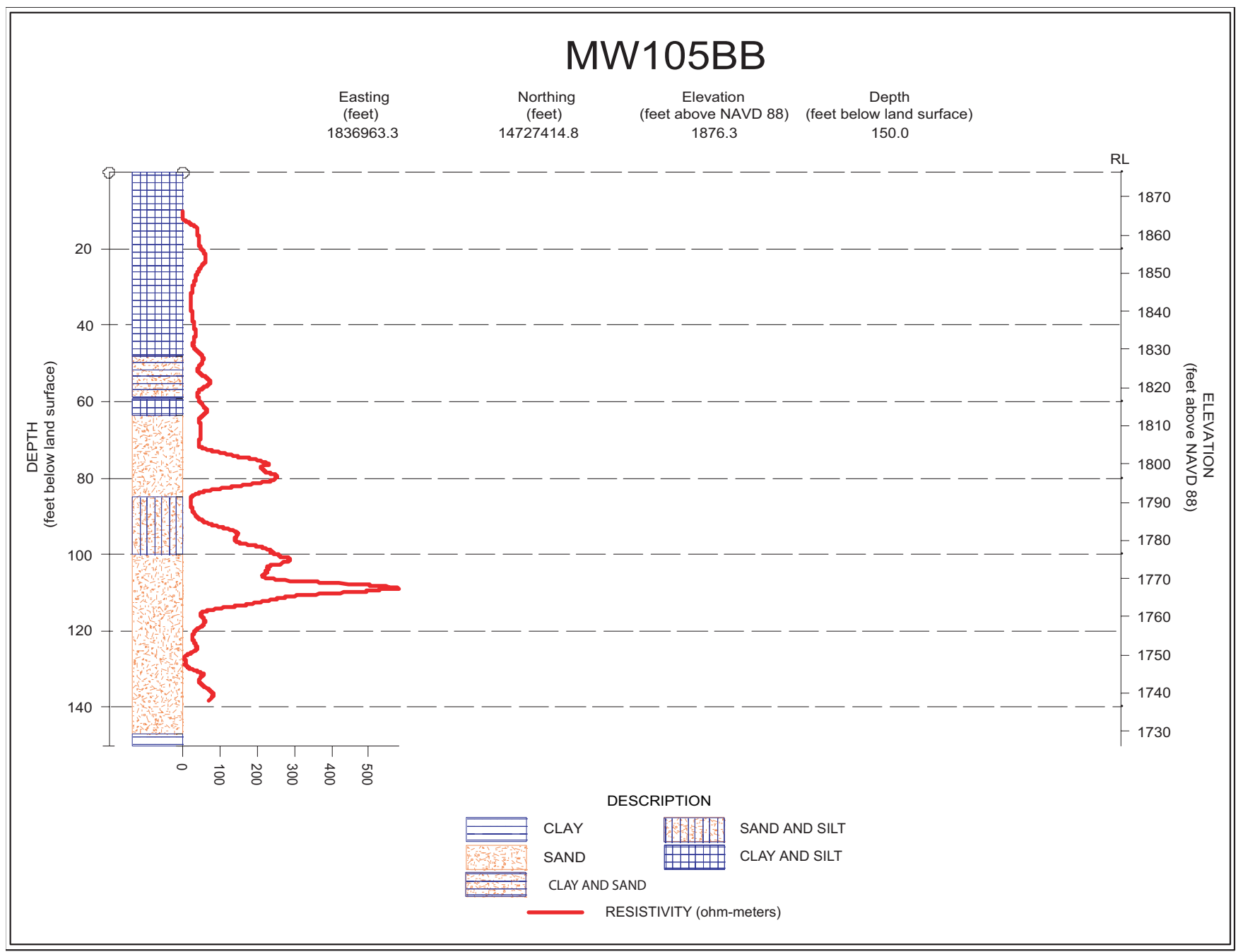

Figure 7d. Geologist log and borehole geophysical resistivity log for monitoring well MW105BB. 


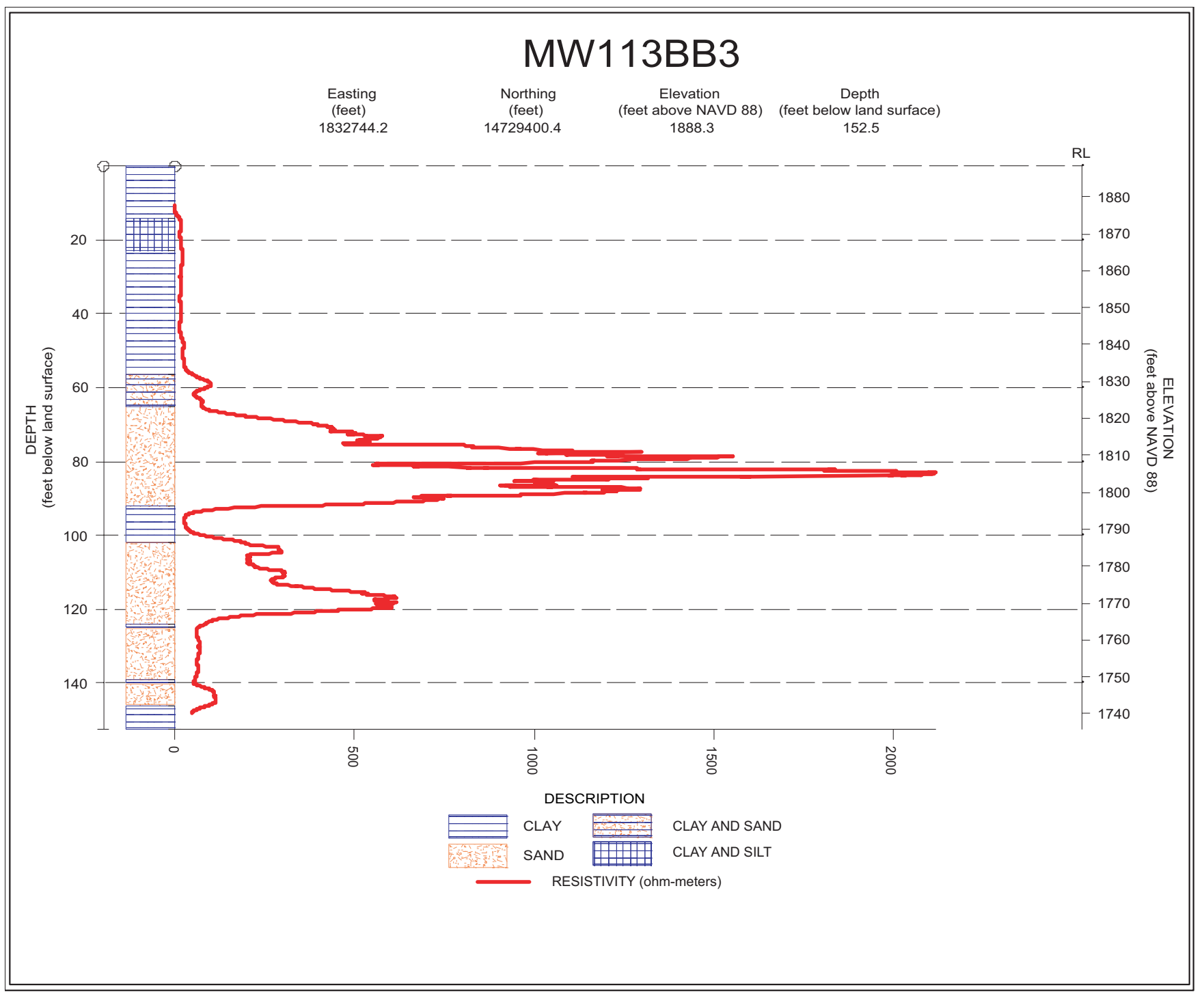

Figure 7e. Geologist log and borehole geophysical resistivity log for monitoring well MW113BB3. 


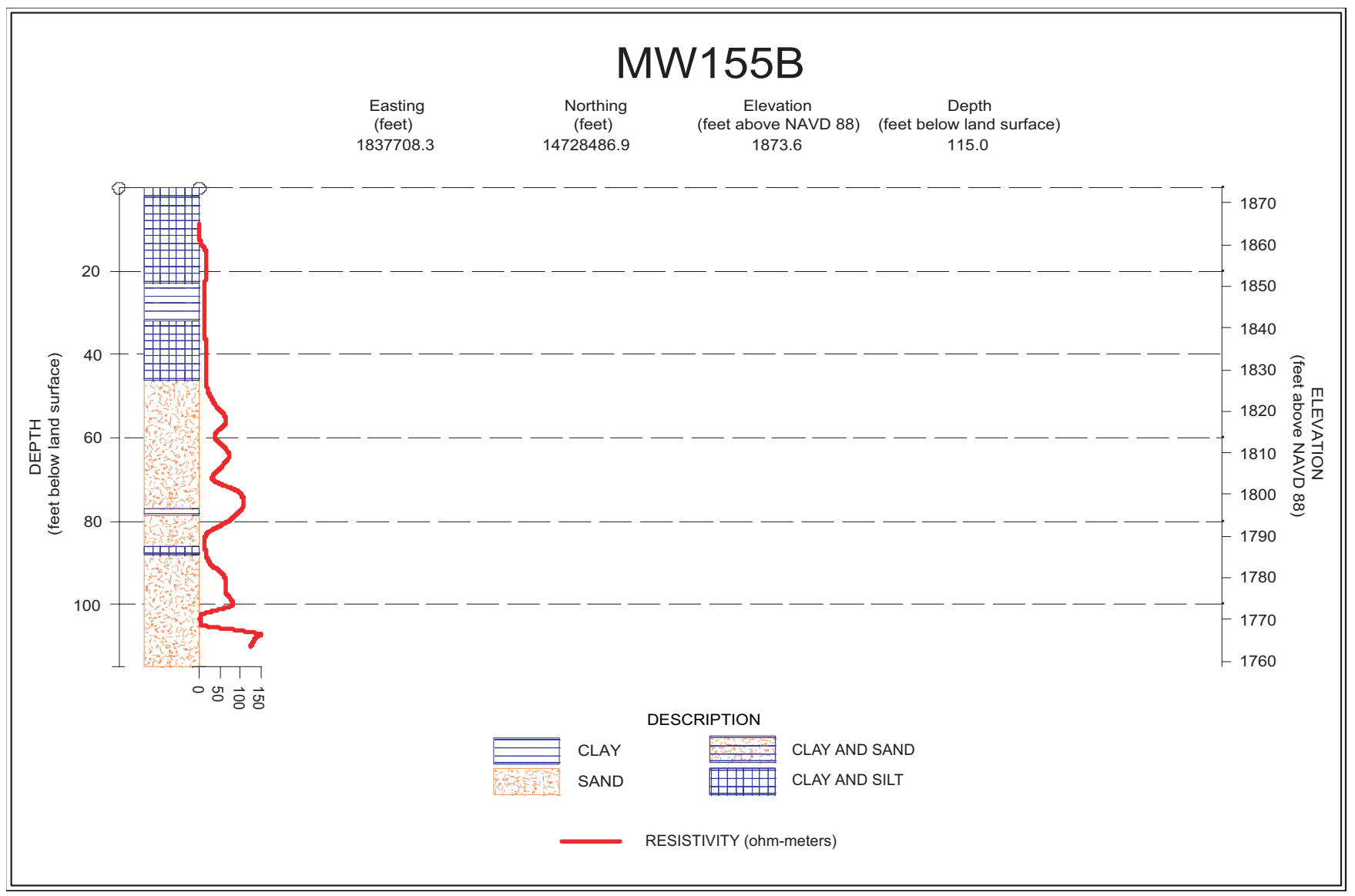

Figure 7f. Geologist log and borehole geophysical resistivity log for monitoring well MW155B. 


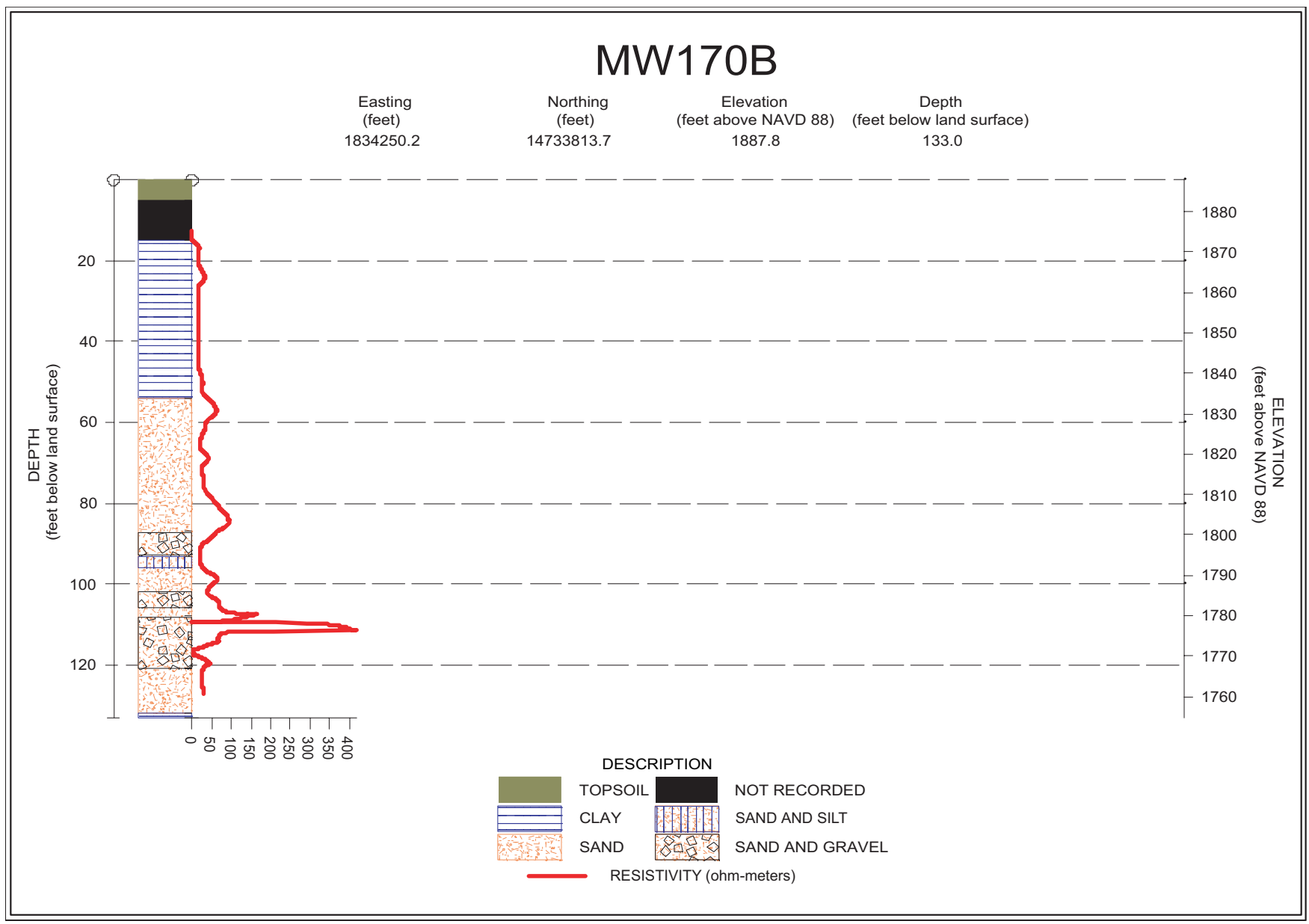

Figure 7g. Geologist log and borehole geophysical resistivity log for monitoring well MW170B. 


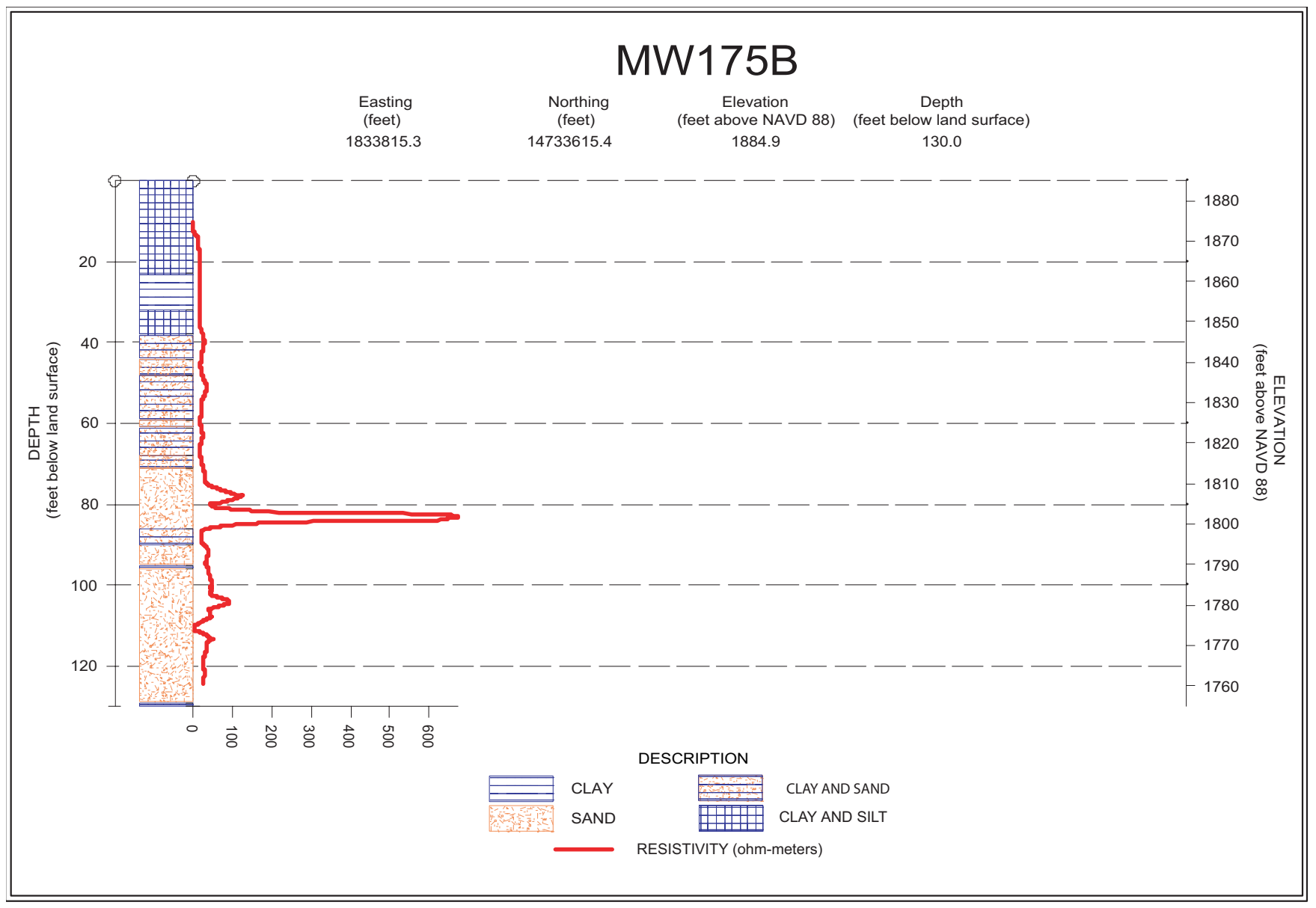

Figure 7h. Geologist log and borehole geophysical resistivity log for monitoring well MW175B. 
Appendix 2-Inversion Results of Two-Dimensional Direct-Current Resistivity 
Blank Page 


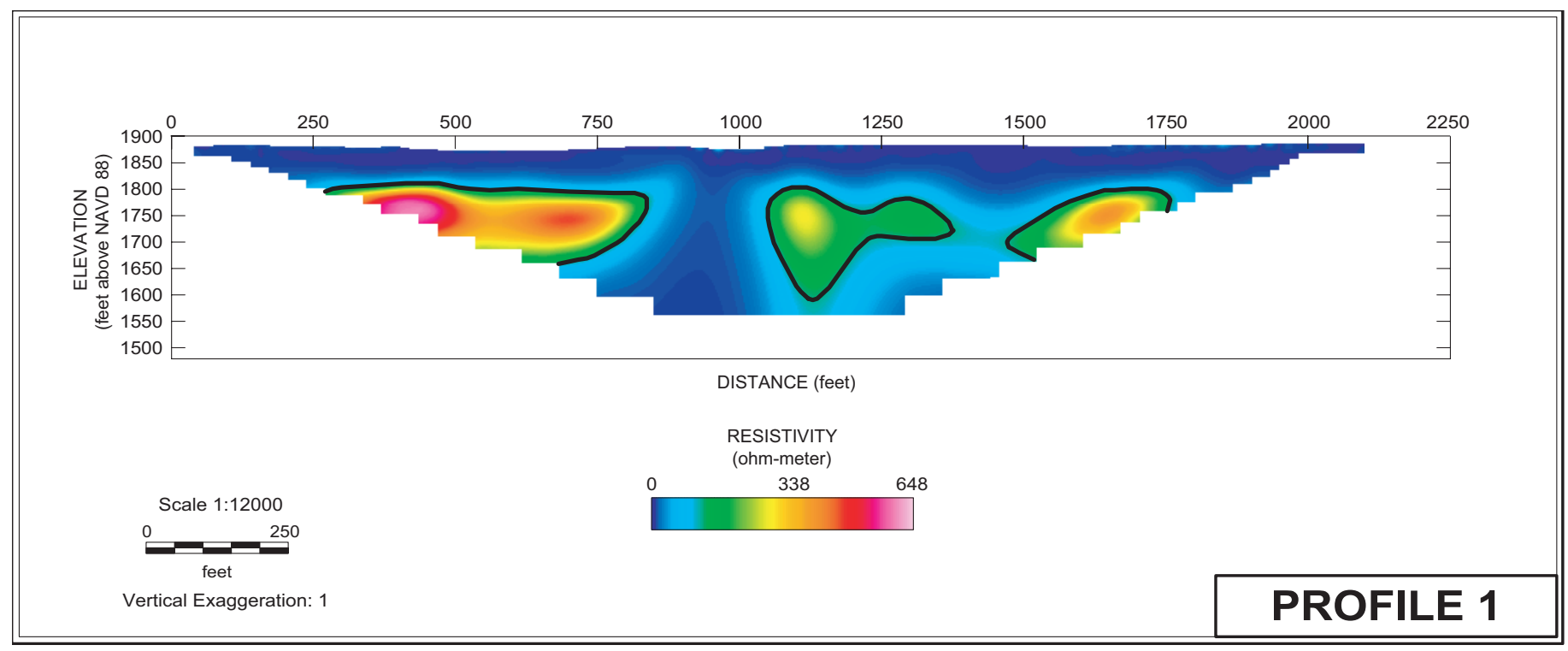

Figure 8a. Inversion results of two-dimensional direct-current resistivity for profile 1.

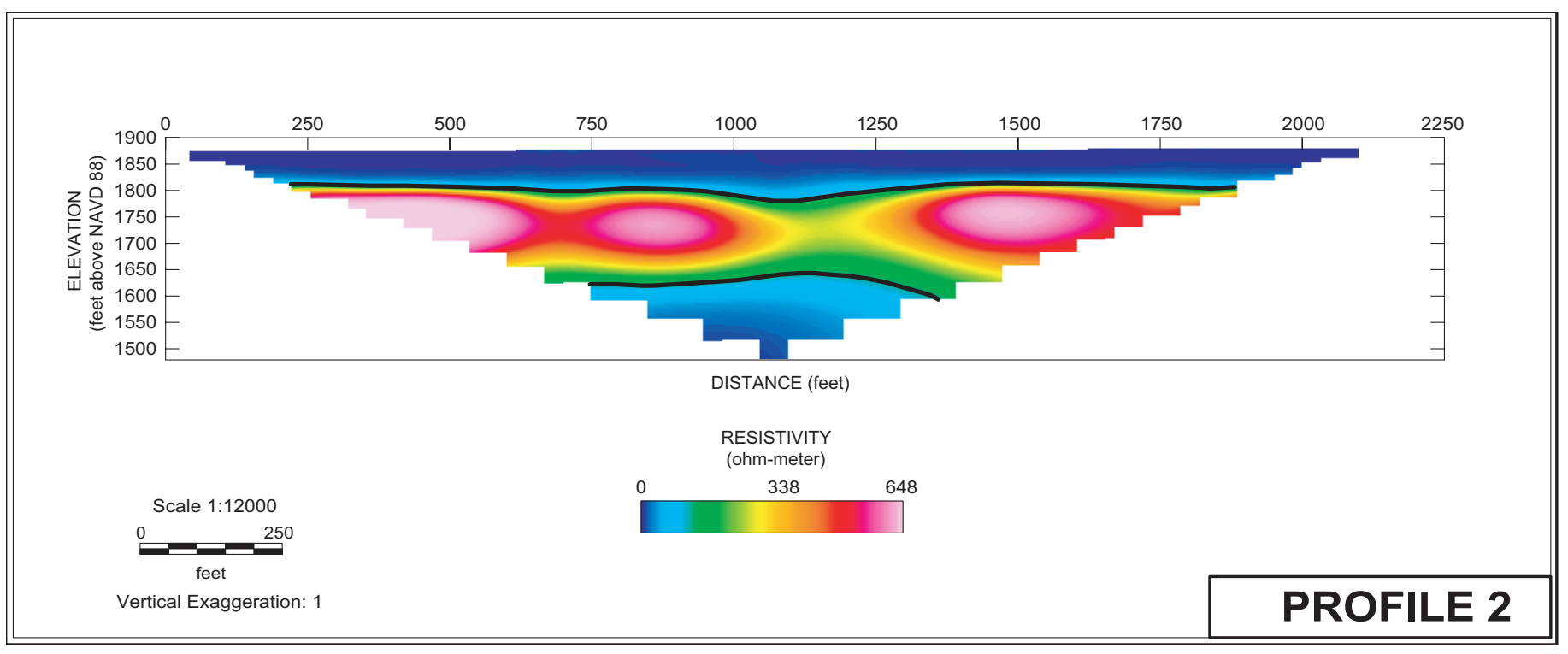

Figure 8b. Inversion results of two-dimensional direct-current resistivity for profile 2. 


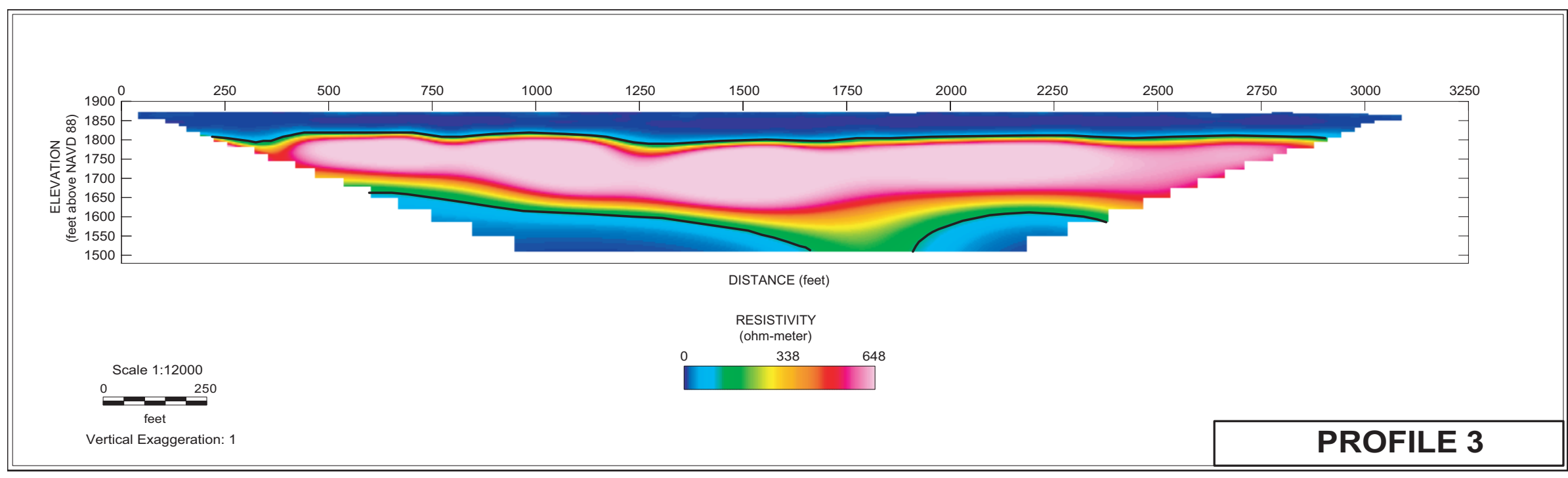

Figure 8c. Inversion results of two-dimensional direct-current resistivity for profile 3.

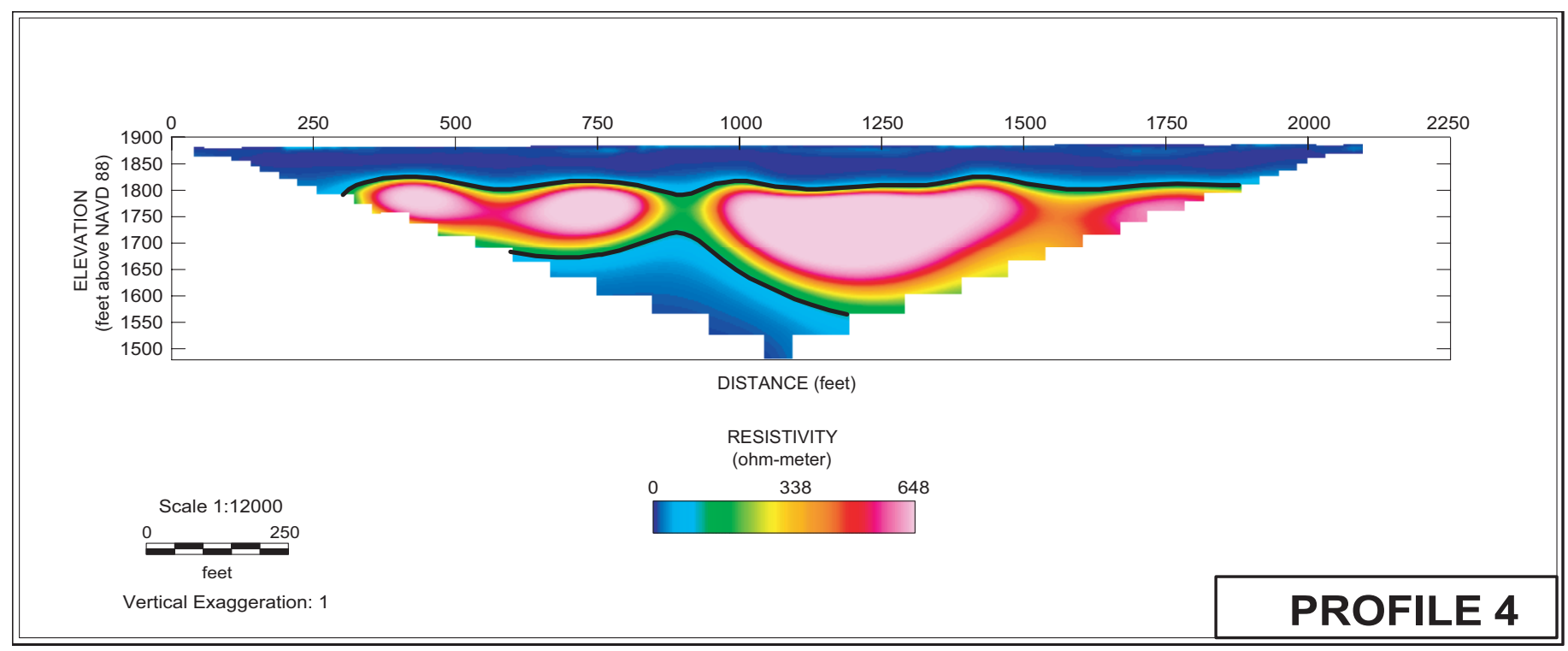




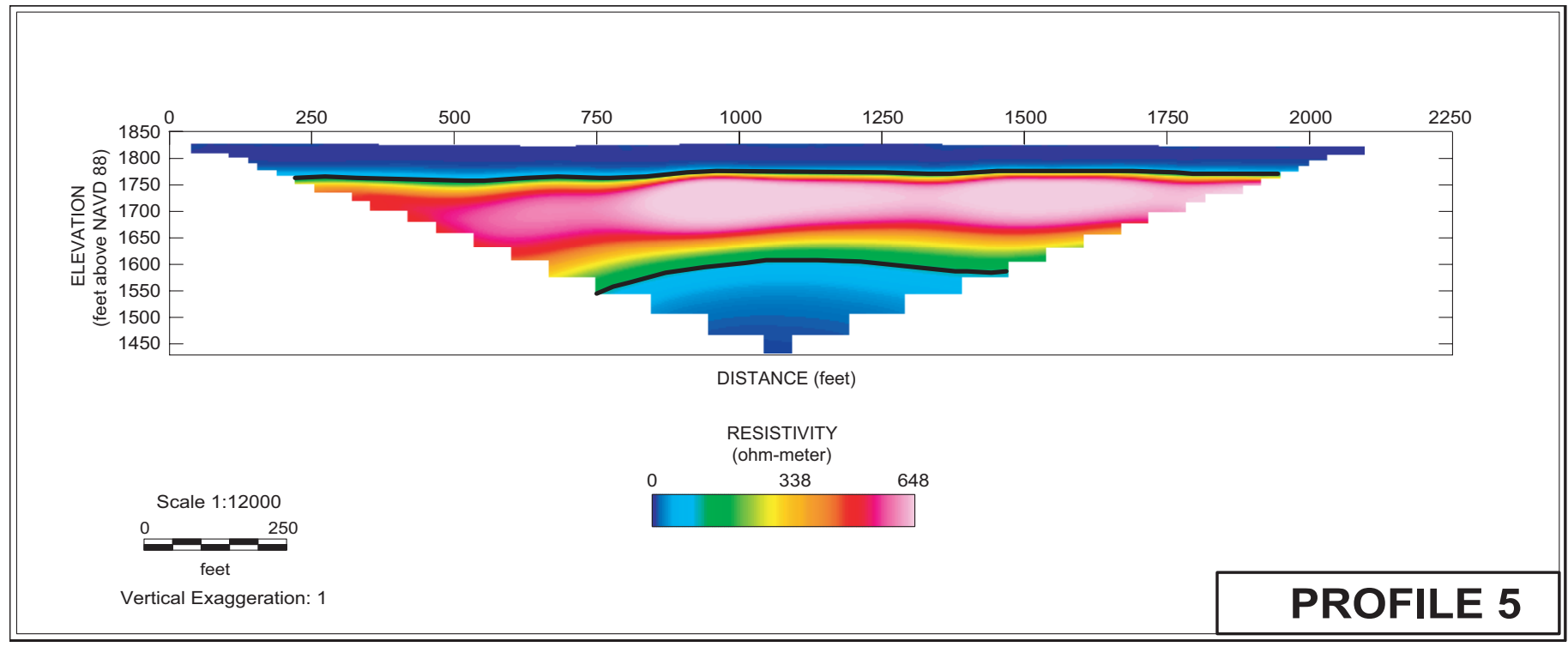

Figure 8e. Inversion results of two-dimensional direct-current resistivity for profile 5 .

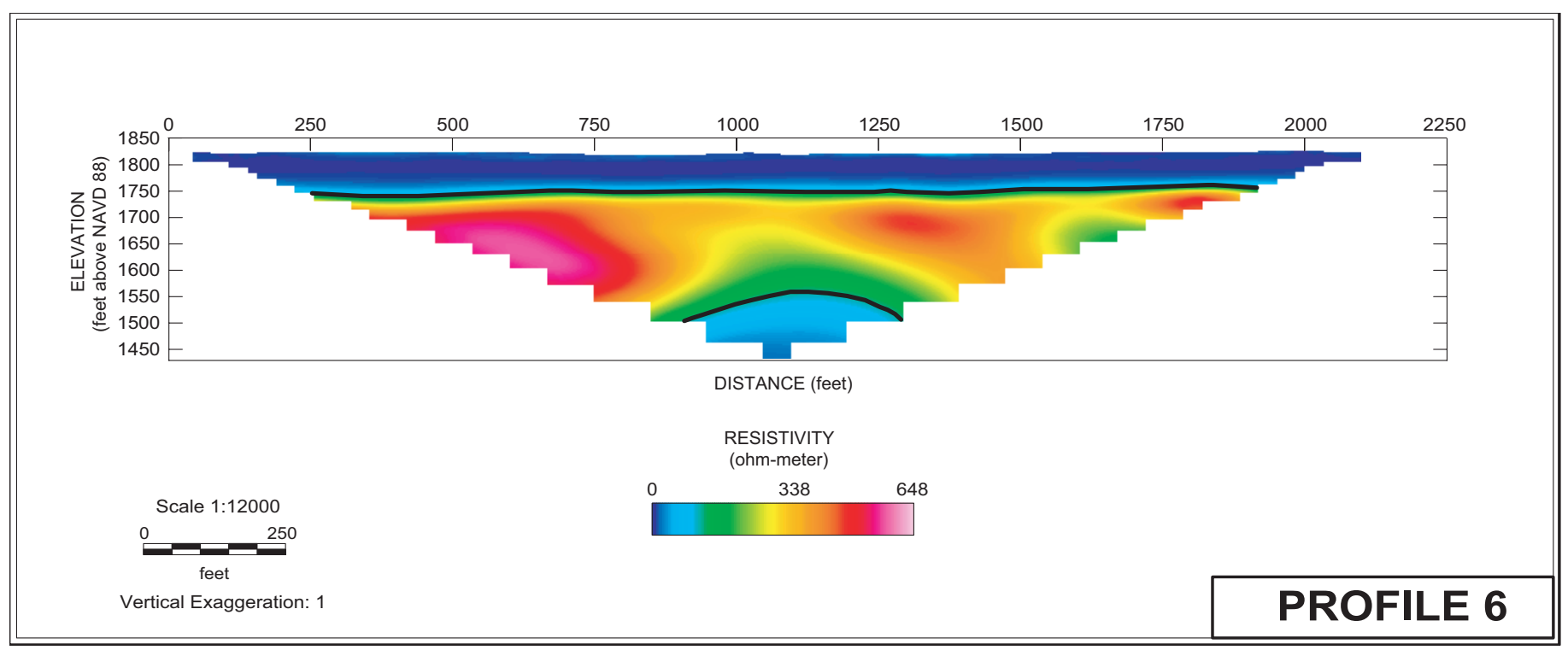

Figure 8f. Inversion results of two-dimensional direct-current resistivity for profile 6 . 